\title{
Paleoceanography
}

\section{RESEARCH ARTICLE \\ 10.1002/2014PA002745 \\ Antarctic Zone nutrient conditions during the last two glacial cycles}

Key Points:

- Antarctic Zone nitrate consumption tightly coupled to Antarctic climate

- Glacial Antarctic Zone characterized by reduced nitrate seasonality

- Iron availability controls annual Antarctic Zone export production

Supporting Information:

- Figures S1-S4

- Table S1

Correspondence to:

A. S. Studer,

studer@princeton.edu;

anja.studer@erdw.ethz.ch

Citation:

Studer, A. S., et al. (2015), Antarctic Zone nutrient conditions during the last two glacial cycles, Paleoceanography, 30, doi:10.1002/2014PA002745.

Received 24 OCT 2014 Accepted 4 JUN 2015

Accepted article online 9 JUN 2015

(c)2015. American Geophysical Union. All Rights Reserved.

\author{
Anja S. Studer ${ }^{1,2}$, Daniel M. Sigman ${ }^{1}$, Alfredo Martínez-García ${ }^{2}$, Verena Benz ${ }^{3}$, Gisela Winckler ${ }^{4,5}$, \\ Gerhard Kuhn ${ }^{3}$, Oliver Esper ${ }^{3}$, Frank Lamy ${ }^{3}$, Samuel L. Jaccard ${ }^{6}$, Lukas Wacker ${ }^{7}$, Sergey Oleynik ${ }^{1}$, \\ Rainer Gersonde ${ }^{3}$, and Gerald H. Haug ${ }^{2}$
}

\begin{abstract}
${ }^{1}$ Department of Geosciences, Princeton University, Princeton, New Jersey, USA, ${ }^{2}$ Geological Institute, ETH Zurich, Zurich, Switzerland, ${ }^{3}$ Alfred-Wegener-Institut, Helmholtz-Zentrum für Polar- und Meeresforschung, Bremerhaven, Germany, ${ }^{4}$ Lamont-Doherty Earth Observatory, Columbia University, Palisades, New York, USA, ${ }^{5}$ Department of Earth and Environmental Sciences, Columbia University, Palisades, New York, USA, ${ }^{6}$ Institute of Geological Sciences and Oeschger Centre for Climate Change Research, University of Bern, Bern, Switzerland, 'aboratory of Ion Beam Physics, ETH Zurich, Zurich, Switzerland
\end{abstract}

\begin{abstract}
In a sediment core from the Pacific sector of the Antarctic Zone (AZ) of the Southern Ocean, we report diatom-bound $\mathrm{N}$ isotope $\left(\delta^{15} \mathrm{~N}_{\mathrm{db}}\right)$ records for total recoverable diatoms and two distinct diatom assemblages (pennate and centric rich). These data indicate tight coupling between the degree of nitrate consumption and Antarctic climate across the last two glacial cycles, with $\delta^{15} \mathrm{~N}_{\mathrm{db}}$ (and thus the degree of nitrate consumption) increasing at each major Antarctic cooling event. Coupled with evidence from opal- and barium-based proxies for reduced export production during ice ages, the $\delta^{15} \mathrm{~N}_{\mathrm{db}}$ increases point to ice age reductions in the supply of deep ocean-sourced nitrate to the AZ surface. The two diatom assemblages and species abundance data indicate that the $\delta^{15} \mathrm{~N}_{\mathrm{db}}$ changes are not the result of changing species composition. The pennate and centric assemblage $\delta^{15} \mathrm{~N}_{\mathrm{db}}$ records indicate similar changes but with a significant decline in their difference during peak ice ages. A tentative seasonality-based interpretation of the centric-to-pennate $\delta^{15} \mathrm{~N}_{\mathrm{db}}$ difference suggests that late summer surface waters became nitrate free during the peak glacials.
\end{abstract}

\section{Introduction}

The high concentrations of nitrate and phosphate in Antarctic Zone (AZ) surface waters ultimately derive from the rapid supply of dissolved nutrients from the deep ocean, due to both vertical mixing across the relatively weak pycnocline and the upwelling driven by the southern hemisphere westerly winds. However, Southern Ocean phytoplankton could easily consume these nutrients in the summer if they grew at physiologically maximal rates. Thus, limitations on phytoplankton growth must also play a role, and modern oceanographic studies have pointed to the scarcity of light [Mitchell et al., 1991], iron [Martin et al., 1990], or both [Sunda and Huntsman, 1997]. In the effort to understand this and other "high-nutrient, low-chlorophyll" (HNLC) regions, the Antarctic Zone of the Southern Ocean is particularly important, for several reasons.

First, AZ conditions should have changed dramatically over each glacial cycle. Across the Southern Ocean as a whole, the input of iron-bearing dust appears to have been greater during glacial periods [Lambert et al., 2008; Martínez-García et al., 2009; Lamy et al., 2014]. In the glacial AZ, wintertime sea ice was far more extensive than today, and summertime sea ice was also extended in some regions [Gersonde et al., 2005].

Second, changes in nutrient conditions in the $A Z$ could have dramatic effects on productivity in other regions. The westerly winds drive $A Z$ nutrient-rich surface waters northward into the lower-latitude Subantarctic Zone and also down into the ocean's intermediate depths. These northward transported nutrients are then mixed upward to fuel the productivity in the low-latitude ocean [Sarmiento et al., 2004].

Finally, the incomplete consumption of nitrate and phosphate in AZ surface waters followed by the subduction of those surface waters back into the ocean interior allows once deeply sequestered $\mathrm{CO}_{2}$ to escape to the atmosphere. An increase in the fraction of $A Z$ nutrients that are consumed and exported from the surface in sinking organic matter could thus lower atmospheric $\mathrm{CO}_{2}$ during ice ages, and this possibility has been of interest for decades as a possible explanation for glacial/interglacial $\mathrm{CO}_{2}$ changes [Sarmiento and Toggweiler, 1984; Knox and McElroy, 1984; Siegenthaler and Wenk, 1984]. In addition, data 
on the completeness of nutrient consumption in AZ surface waters at times in the past, when combined with information on the rate of organic matter export from the surface ocean, yield the rate at which dissolved nutrients were carried from deep waters into the AZ surface, which in turn relates to how rapidly deep water was being circulated into the surface ocean-a critical piece of information regarding the physics of the ice age ocean and its role in glacial/interglacial (G/IG) climate and $\mathrm{CO}_{2}$ changes.

The first major finding regarding the fertility of the ice age AZ was that the sinking of biological debris out of the surface ocean (and presumably of organic matter in particular, known as "export production") was greatly reduced relative to today and previous interglacials [Mortlock et al., 1991; Charles et al., 1991; Kumar et al., 1993]. This was initially assumed to indicate poor light conditions for AZ phytoplankton during the last ice age, for example, due to sea ice cover or deeper mixing. Subsequently, based on the finding of higher ${ }^{15} \mathrm{~N} /{ }^{14} \mathrm{~N}$ in sedimentary organic matter, it was argued that nitrate consumption was more complete in $\mathrm{AZ}$ surface waters during glacials [François et al., 1997]. This implies that (1) the supply of nitrate to AZ surface waters was reduced during ice ages and (2) the physical and chemical conditions of the ice age $A Z$ allowed phytoplankton to consume a greater fraction of the nitrate supply than occurs today.

The rationale behind the $\mathrm{N}$ isotope proxy is that the ${ }^{15} \mathrm{~N} /{ }^{14} \mathrm{~N}$ of the sinking flux to the seabed in HNLC regions is thought to reflect the degree to which nitrate has been consumed by phytoplankton in the surface ocean [Altabet and François, 1994]. Since phytoplankton preferentially incorporate the lighter ${ }^{14} \mathrm{~N}$ into their biomass [Waser et al., 1998], the nitrate left behind in the surface ocean becomes enriched in ${ }^{15} \mathrm{~N}$, that is, elevated in $\delta^{15} \mathrm{~N}$, where $\delta^{15} \mathrm{~N}=\left[\left({ }^{15} \mathrm{~N} /{ }^{14} \mathrm{~N}\right)_{\text {sample }} /\left({ }^{15} \mathrm{~N} /{ }^{14} \mathrm{~N}\right)\right.$ atm N2 -1$] \times 1000 \%$. Thus, as the surface nitrate pool is drawn down, phytoplankton biomass records a progressively higher $\delta^{15} \mathrm{~N}$, with the $\delta^{15} \mathrm{~N}$ of the annually integrated particulate $\mathrm{N}$ exported to the seabed thus depending on the degree of nitrate consumption reached by the end of the spring/summer period of rapid growth and export.

Diagenetic alteration during sinking and subsequent burial can bias the $\mathrm{N}$ isotopic composition of the bulk sedimentary matter [Altabet and François, 1994; Robinson et al., 2012, for a synthesis]. Furthermore, allochthonous $\mathrm{N}$, such as clay-bound $\mathrm{N}$ and terrestrial organic $\mathrm{N}$ input, can obfuscate the $\delta^{15} \mathrm{~N}$ relationship between local export production and underlying bulk sediments [Schubert and Calvert, 2001; Meckler et al., 2011]. To circumvent these biases, methods have been developed to measure the $\delta^{15} \mathrm{~N}$ of organic $\mathrm{N}$ intrinsic to microfossils, such as the siliceous frustules of diatoms [Robinson et al., 2004, 2005; Robinson and Sigman, 2008; Brunelle et al., 2007, 2010; Studer et al., 2012, 2013] and the calcareous shells of foraminifera [Ren et al., 2009, 2012; Meckler et al., 2011; Straub et al., 2013a, 2013b], as this organic matter is physically protected from diagenetic loss and sedimentary contamination. However, the use of diatom-bound $\delta^{15} \mathrm{~N}$ $\left(\delta^{15} \mathrm{~N}_{\mathrm{db}}\right)$ introduces new uncertainties. Among the greatest concerns is the possibility that the $\delta^{15} \mathrm{~N}$ relationship between biomass and frustule-bound $\mathrm{N}$ varies among species, such that changes in diatom species assemblage through time would drive $\delta^{15} \mathrm{~N}_{\mathrm{db}}$ changes unrelated to the $\delta^{15} \mathrm{~N}$ of diatom biomass [Jacot Des Combes et al., 2008; Horn et al., 2011].

Previous studies reconstructing the degree of nitrate consumption in the Antarctic Zone of the Southern Ocean using diatom-bound $\mathrm{N}$ isotopes have shown heterogeneous results. Some of the published $\delta^{15} \mathrm{~N}_{\mathrm{db}}$ records from the AZ occur in the context of dramatic downcore changes in diatom species assemblage [Jacot Des Combes et al., 2008; Horn et al., 2011], while others are of low temporal resolution and/or have a poorly constrained age model, which has made it difficult to go beyond general $\mathrm{G} / \mathrm{IG}$ changes in $\delta^{15} \mathrm{~N}_{\mathrm{db}}$. Comparison of the available downcore records from the Pacific, Indian, and Atlantic sectors of the AZ suggests a general tendency of higher nutrient consumption during the Last Glacial Maximum (LGM) but with some exceptions and some evidence for major changes within the last ice age [Robinson and Sigman, 2008].

Here in a sediment core from the open Antarctic Zone in the Pacific sector, we report a set of detailed diatombound $\mathrm{N}$ isotope records over two glacial cycles, which begin to address the diatom assemblage question, show by far the most robust coupling to date of AZ nutrient conditions to glacial cycles, and may provide the first information on the response of the seasonality in AZ nutrient conditions to glacial cycles.

\section{Materials, Methods, and Proxies}

Gravity core PS75/072-4 was retrieved during the ANTXXVI/2 expedition from the Pacific sector of the Southern Ocean ( $57^{\circ} 33.51^{\prime} \mathrm{S}, 151^{\circ} 13.17^{\prime} \mathrm{W}$, water depth $3099 \mathrm{~m}$; Figure 1 ), located $\sim 1.2^{\circ}$ south of the present-day position 


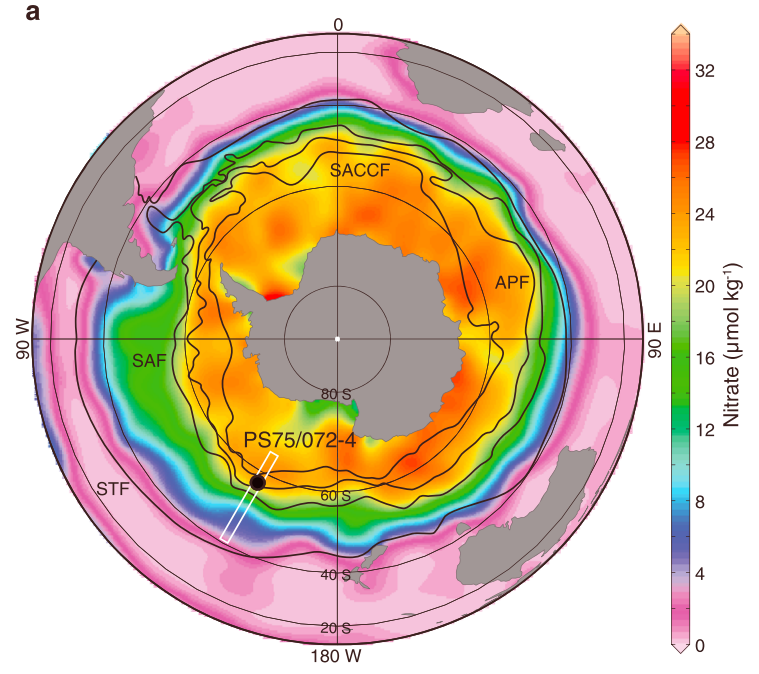

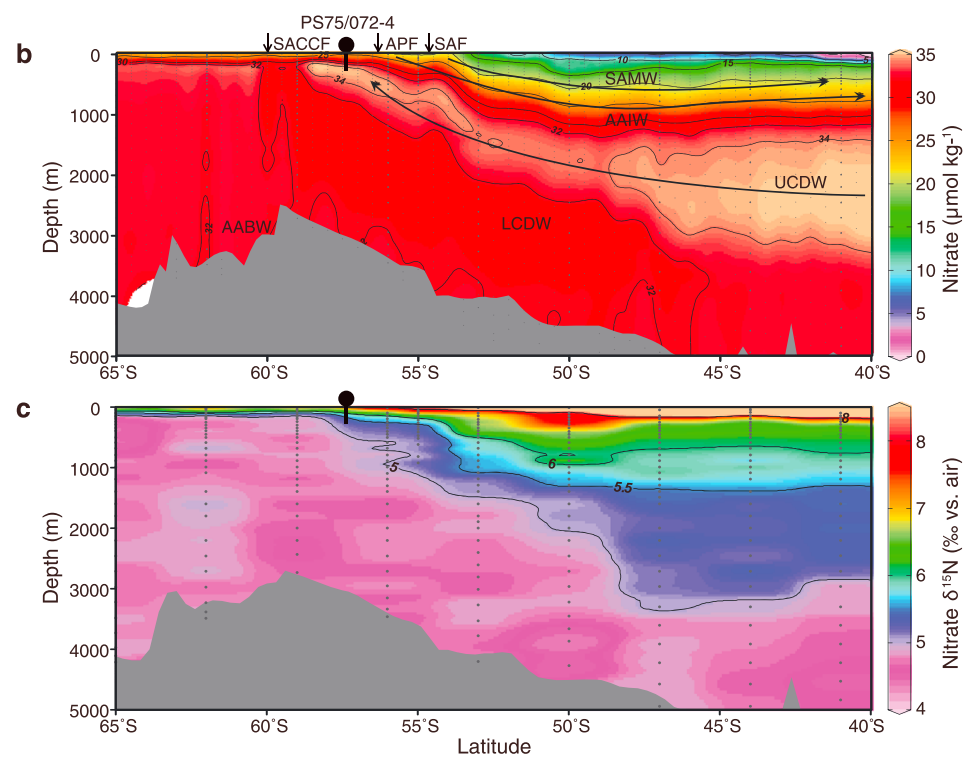

Figure 1. Core location in the context of nitrate concentration and $\delta^{15} \mathrm{~N}$. Sediment core PS75/072-4 (black circle). (a) Map of austral summer (January-March) sea surface nitrate concentration. (b and c) Meridional depth sections of nitrate concentration and $\delta{ }^{15} \mathrm{~N}$ along Line P16 [Rafter et al., 2013 ].The location of the meridional depth sections in Figures $1 \mathrm{~b}$ and $1 \mathrm{c}$ is shown as a white rectangle in Figure 1a. STF = Subtropical Front; SAF = Subantarctic Front; APF $=$ Antarctic Polar Front; SACCF = Southern Antarctic Circumpolar Current Front; UCDW = Upper Circumpolar Deep Water; LCDW = Lower Circumpolar Deep Water; AABW = Antarctic Bottom Water; AAIW = Antarctic Intermediate Water; SAMW = Subantarctic Mode Water. The maps were generated using Ocean Data View [Schlitzer, 2002].

of the polar front and north of the Southern Antarctic Circumpolar Current Front (SACCF) and the modern winter sea ice edge. The $9.61 \mathrm{~m}$ long sediment core consists of diatom ooze with variable amounts of siliciclastics and foraminifera.

\subsection{Age Model and Radiocarbon Dating}

The stratigraphy of the sediment core is based mainly on (1) five accelerator mass spectrometry (AMS) ${ }^{14} \mathrm{C}$ dates on the planktonic foraminifera Neogloboquadrina pachyderma (sin.) (Figure 2, black triangles on top) and (2) the correlation of the $\delta^{18} \mathrm{O}$ of $N$. pachyderma (sin.) to the European Project for Ice Coring in Antarctica (EPICA) Dome $C \delta$ D record [Jouzel et al., 2007] (blue triangles), as the sharp $\delta^{18} O$ changes (e.g., the one depth (but replicated) $\delta^{18} \mathrm{O}$ maximum within the last deglaciation) are best explained as a temperature response. For the deeper part of the core, where carbonate is lacking (the marine oxygen isotope stage (MIS) 7/6 transition), Ba/Fe elemental ratios were correlated to EPICA Dome $C \delta D$ (purple triangle) based on Jaccard et al. [2013], maintaining similar sedimentation rates to those observed for MIS 4 and the MIS 5/4 transition. An additional tie point at $\sim 190 \mathrm{ka}$ (pink triangle) comes from the biostratigraphic constraint of the last appearance datum of the diatom Hemidiscus karstenii [Zielinski and Gersonde, 2002].

The ${ }^{14} \mathrm{C}$ dating was performed at ETH Zurich on an AMS system fitted with a gas ion source [Wacker et al., 2013]. The planktonic foraminifera N. pachyderma (sin.) were handpicked from the $125-250 \mu \mathrm{m}$ size fraction and cleaned using the protocol of Barker et al. [2003], with the modifications of Skinner et al. [2010]. About 250-900 $\mu \mathrm{g}$ of forams were weighed into clean $3 \mathrm{~mL}$ Exetainer vials (Labco, UK), sealed, degassed with helium, and reacted with phosphoric acid to $\mathrm{CO}_{2}$, which was fed to the gas ion source of the AMS system [Wacker et al., 2013]. The radiocarbon ages were calibrated using the calibration program Calib 6.1.0 [Stuiver and Reimer, 1986] and the calibration curve Marine09 [Reimer et al., 2009], after applying a constant reservoir age of 590 years [Bard, 1988]. Additional samples from the last glacial and early deglacial were dated, but both the uncertainty in Antarctic upper ocean reservoir age through time as well as the lower carbonate content of these samples (and therefore greater possibility of down-working and contamination with younger sediments across carbonate gradients) discouraged the use of these ages as radiocarbon tie points. The ${ }^{14} \mathrm{C}$ tie points are given in Table $\mathrm{S} 1$ in the supporting information. While the temporal structure of changes through the deglaciations is of great importance, we will pursue elsewhere 


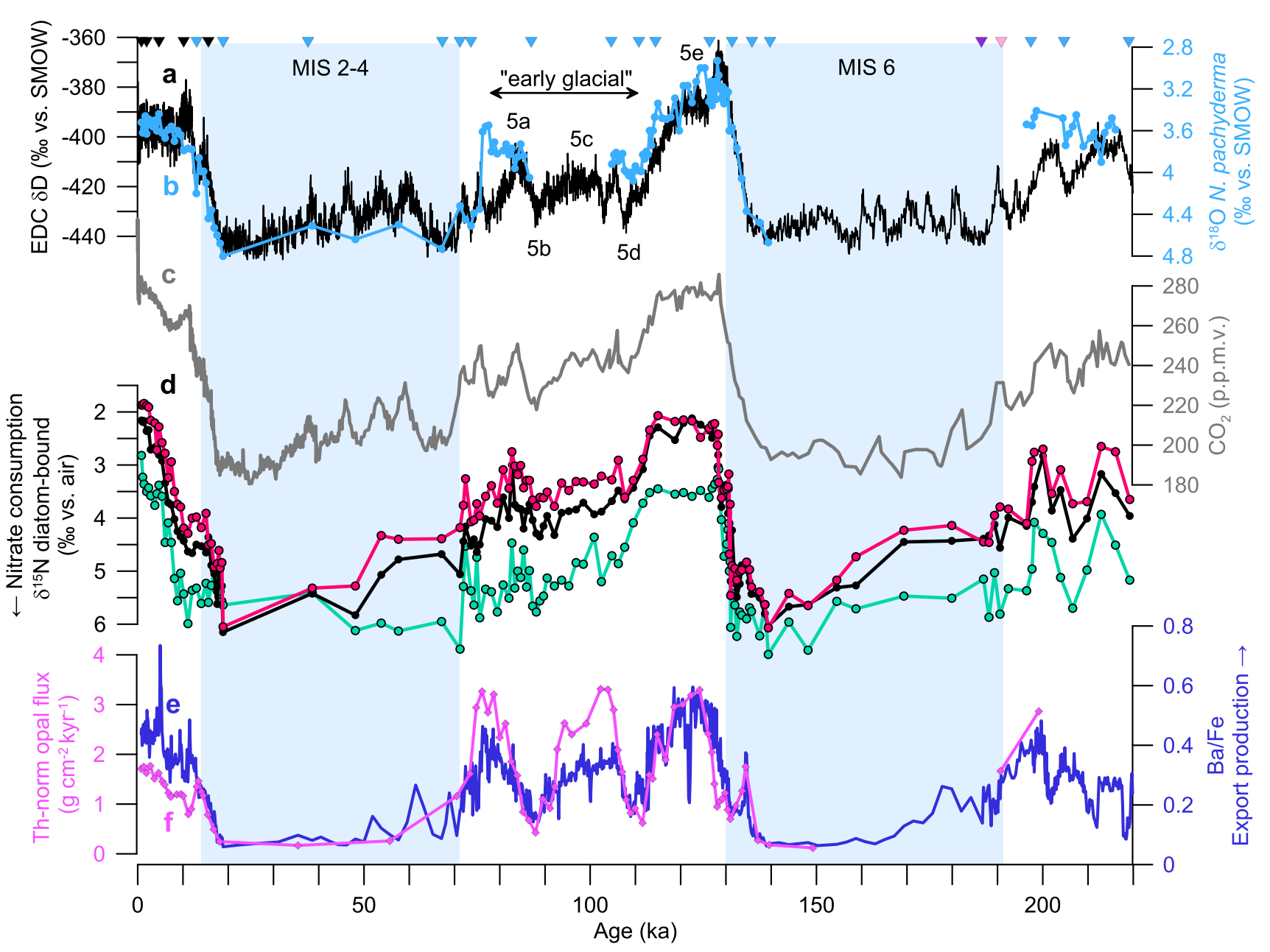

Figure 2. Proxies for global climate and nitrate consumption and productivity across the last two glacial cycles in the Antarctic Zone of the Southern Ocean. (a) EPICA Dome C $\delta$ D record, a proxy for Antarctic air temperatures [Jouzel et al., 2007]. (b) The $\delta^{18} \mathrm{O}$ measured on the planktonic foraminifera Neogloboquadrina pachyderma (sin.). (c) Ice core-derived atmospheric $p \mathrm{CO}_{2}$ composite record [Bereiter et al., 2015; Marcott et al., 2014; Ahn and Brook, 2014; Schneider et al., 2013; Rubino et al., 2013; Bereiter et al., 2012; MacFarling Meure et al., 2006; Monnin et al., 2004, 2001; Petit et al., 1999]. (d) Diatom-bound $\delta^{15} \mathrm{~N}$ measured on the total (black), pennate (red), and centric (light green) diatom assemblage. The $\delta^{15} \mathrm{~N}$ scale is inverted such that the interpreted fraction of remaining nitrate (and thus typically surface nitrate concentration) is upward. (e) XRF-derived Ba/Fe elemental ratio (blue), a reflection of export production [Jaccard et al., 2013]. (f) The ${ }^{230}$ Th-normalized biogenic opal flux (purple), a measure of diatom productivity [Anderson et al., 2009]. The age model tiepoints are indicated with triangles on the top (black for radiocarbon, blue for $\delta^{18} \mathrm{O}$, purple for $\mathrm{Ba} / \mathrm{Fe}$, and pink for diatom biostratigraphy). The blue shadings indicate glacial stages.

the deglacial timing of changes in the biogeochemical proxies, so as to allow for a more complete description of the dependence of our conclusions on the sediment core age model.

\subsection{Diatom-Bound $\delta^{15} \mathrm{~N}$ Analysis}

The isotopic composition of the organic $\mathrm{N}$ encapsulated in the diatom frustules $\left(\delta^{15} \mathrm{~N}_{\mathrm{db}}\right)$ was determined on the total diatom opal as well as on individual fractions dominated by centric and pennate diatom species, respectively, providing three analytically independent records of past $\mathrm{N}$ isotope dynamics. The $\delta^{15} \mathrm{~N}_{\mathrm{db}}$ was measured at Princeton University by a wet chemical oxidation coupled to the denitrifier method [Robinson et al., 2004; Knapp et al., 2005] after separation of the diatom opal from the bulk sediment. The protocol followed that of Studer et al. [2013], with minor modifications as follows. To reduce sporadic contamination by radiolaria the sediment was wet sieved with the $<100 \mu \mathrm{m}$ fraction retained for analysis, with the exception of the glacial age sediments (MISs $2-4$ and 6), of which the $<100 \mu \mathrm{m}$ fraction was retained. This sieving size difference did not introduce a significant systematic bias (Figure S1 in the supporting information). For each depth sample, two separate diatom opal extractions were made. The first was used for total diatom $\delta^{15} \mathrm{~N}_{\mathrm{db}}$ analysis while the second was split into a pennate diatom fraction (dominated by 

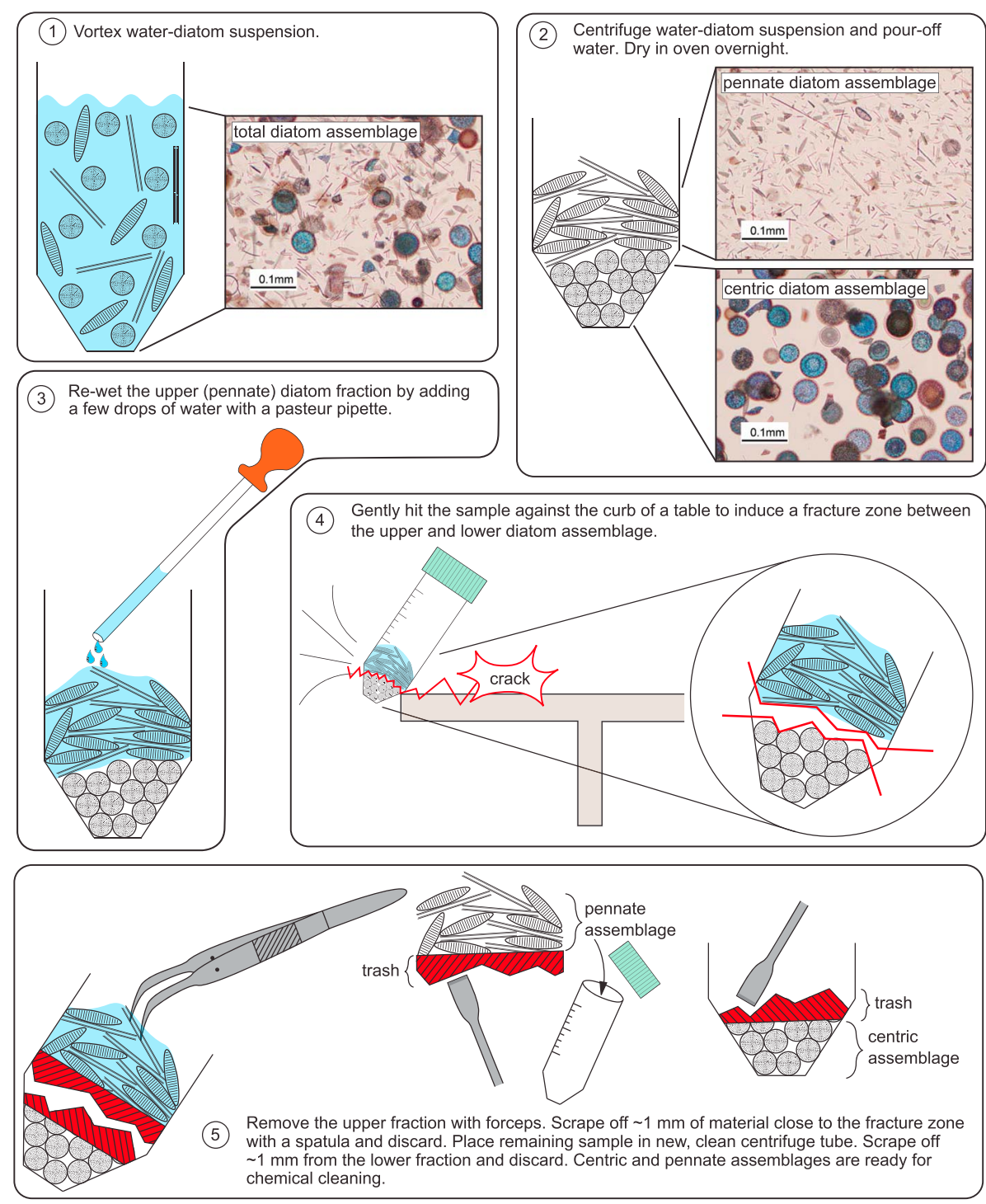

Figure 3. Cartoon of the separation technique developed to isolate the centric and pennate diatoms from the total diatom assemblage. The centric/pennate separation was achieved by centrifuging the suspended diatom slurry, causing the hydrodynamically "heavier" centric diatoms to accumulate at the bottom of the centrifuge tube, while the pennate diatoms accumulated in the upper part of the sedimented fraction. After the diatom opal was dried at $60^{\circ} \mathrm{C}$, the pennate fraction was rewetted with a few drops of distilled water, and a fracture was induced between the centric and pennate assemblage by tapping the centrifuge tube against the curb of a table. The pennate fraction was then removed with forceps and placed in a new centrifuge tube, while the centric diatom fraction adhered to the bottom of the tube.

Fragilariopsis spp.) and a centric diatom fraction (dominated by Thalassiosira lentiginosa) (Figure 3). The separated diatom opal was chemically cleaned, first in a reductive step to remove metal coatings and then in an oxidative step to remove labile organic matter on the frustule surfaces. The cleaned diatom opal was dissolved and the organic nitrogen released from the frustules oxidized to nitrate in a $1 \mathrm{M}$ sodium hydroxide and $0.15 \mathrm{M}$ potassium persulfate solution in an autoclave at $121^{\circ} \mathrm{C}$ for $60 \mathrm{~min}$. The concentration of the nitrate in the solution was determined by chemiluminescence [Braman and Hendrix, 1989]. An aliquot of the nitrate solution equivalent to $10 \mathrm{nmol}$ of $\mathrm{N}$ was converted to nitrous oxide $\left(\mathrm{N}_{2} \mathrm{O}\right)$ by the denitrifier method [Sigman et al., 2001]. The $\delta^{15} \mathrm{~N}$ of the $\mathrm{N}_{2} \mathrm{O}$ was determined by a purpose-built purge, trap, gas chromatography inlet system [Casciotti et al., 2002] online to a Thermo MAT253 stable isotope ratio mass spectrometer. Replicate analyses for samples and oxidation replicates indicate an average standard deviation of $0.1 \%$ for the pennate fraction and $0.3 \%$ for the total diatom and centric fraction and $0.1 \%$ o for replicates of the nitrate isotopic analysis (all fractions). 


\subsection{XRF Scanning and Absolute Elemental Concentrations}

Previous studies have shown that the sedimentary $\mathrm{Ba} / \mathrm{Fe}$ ratio reflects the biogenic flux of barium to the seabed [Jaccard et al., 2013], a useful proxy for integrated export production [Dymond et al., 1992]. The relative sedimentary elemental concentrations ( $\mathrm{Ba}$ and $\mathrm{Fe}$ ) were determined by X-ray fluorescence scanning on an Avaatech core scanner at Alfred Wegener Institute, Bremerhaven. Data were obtained at a $1 \mathrm{~cm}$ resolution over an area of $1.2 \mathrm{~cm}^{2}$ (spot size: $1 \mathrm{~cm}$ downcore $\times 1.2 \mathrm{~cm}$ width) at the split core surface of the archive half. Ba was measured for $30 \mathrm{~s}$ (life time) at $50 \mathrm{kV}$, Fe for $10 \mathrm{~s}$ at $10 \mathrm{kV}$. Absolute elemental concentrations of major elements ( $\mathrm{Fe}$ ) were measured by inductively coupled plasma (ICP)-optical emission spectroscopy (Varian Vista Pro), while minor elements $(\mathrm{Ba})$ were measured by ICP-mass spectrometry (Perkin-Elmer ELAN 9000) by ALS Chemex Ltd, North Vancouver, Canada. Accuracy was better than $5 \%$ and $2 \%$, respectively, for replicate measurements. The absolute elemental concentrations of $\mathrm{Ba}$ and Fe were used to calibrate the XRF scanning data, and the reported $\mathrm{Ba} / \mathrm{Fe}$ ratios thus represent absolute element ratios.

\subsection{Biogenic Opal}

The concentration of biogenical opal was measured by the sequential leaching method [Müller and Schneider, 1993], porewater salt corrected [Kuhn, 2013].

\subsection{Uranium and Thorium Isotope Analysis}

In addition to the $\mathrm{Ba} / \mathrm{Fe}$ ratio, the ${ }^{230}$ Th-normalized biogenic opal flux was determined, providing a complementary measure of diatom export and thus, by inference, silicate supply to the core site. Uranium and thorium isotope abundances were measured at Lamont-Doherty Earth Observatory by isotope dilution using an Axiom single-collector ICP-MS [Fleisher and Anderson, 2003]. The ${ }^{230} \mathrm{Th}_{\mathrm{xs}}$-normalized fluxes were calculated (for a recent review, see François et al. [2004]) using the following equation: $F=\beta_{230} \times z / x s^{230} \mathrm{Th}_{0}$, where $\beta_{230}$ is the water column production rate of ${ }^{230} \mathrm{Th}\left(0.0256 \mathrm{dpm} \mathrm{m}^{-3} \mathrm{yr}^{-1}\right), z$ is the water depth, and $x s^{230} \mathrm{Th}_{0}$ is the excess sedimentary ${ }^{230} \mathrm{Th}$ concentration in $\mathrm{dpm} \mathrm{g}^{-1}$ corrected for (a) the fraction of the in situ-produced ${ }^{230} \mathrm{Th}$ supported by the decay of ${ }^{238} \mathrm{U}$ within lithogenic material assuming a mean regional detrital ${ }^{238} \mathrm{U} /{ }^{232} \mathrm{Th}$ activity ratio of $0.4 \pm 0.1$ [Henderson and Anderson, 2003], (b) the fraction of the in situproduced ${ }^{230}$ Th by the decay of authigenic ${ }^{238} \mathrm{U}$, and (c) the radioactive decay.

\subsection{Diatom Slide Preparation and Counting}

In order to determine the diatom species composition throughout the core, quantitative diatom slides of core PS75/072-4 were prepared according to the standard technique developed in the micropaleontological laboratory at the Alfred Wegener Institute in Bremerhaven [Gersonde and Zielinski, 2000]. Diatom counting followed the methods of Schrader and Gersonde [1987]. On average, around 550 valves were counted per sample (minimum 400) with a Zeiss microscope at 1000X magnification and identified to species or species-group level. The taxonomy and the grouping of diatom species and varieties followed Hasle and Syvertsen [1996] and Zielinski and Gersonde [1997].

\section{Results}

\subsection{Diatom-Bound Nitrogen Isotopes}

Over the last two glacial cycles, total diatom $\delta^{15} \mathrm{~N}_{\mathrm{db}}$ is consistently higher during glacials (by up to $\sim 4 \%$; Figure $2 \mathrm{~d}$ ), indicating that the $\mathrm{AZ}$ surface ocean was characterized by more complete nitrate consumption. Starting from the previous interglacial (MIS 5e), $\delta^{15} \mathrm{~N}_{\mathrm{db}}$ increases in three steps toward full glacial conditions. The first major $\delta^{15} \mathrm{~N}_{\mathrm{db}}$ rise occurs at the end of the penultimate interglacial, at the MIS $5 \mathrm{e} / 5 \mathrm{~d}$ transition $(\sim 115 \mathrm{ka})$. Following the period of relatively stable $\delta^{15} \mathrm{~N}_{\mathrm{db}}$ during MISs $5 \mathrm{~d}$ to $5 \mathrm{a}, \delta^{15} \mathrm{~N}_{\mathrm{db}}$ rises again by $\sim 1 \%$ at the MIS 5/4 transition ( 70 ka). From MIS 4 onward, it appears that $\delta^{15} \mathrm{~N}_{\mathrm{db}}$ increases by an additional $1 \%$, reaching peak values during MIS 2 (LGM). The deglaciations are characterized by $\delta^{15} \mathrm{~N}_{\mathrm{db}}$ declines on the order of 3.5\%o, apparently occurring in two steps.

The two separated diatom assemblages, centrics and pennates, show distinct $\mathrm{N}$ isotopic signatures. Centric diatom $\delta^{15} \mathrm{~N}_{\mathrm{db}}$ is on average $1.3 \%$ o higher than pennate $\delta^{15} \mathrm{~N}_{\mathrm{db}}$, although the centric-pennate offset varies through time. The centric-pennate difference appears to increase from interglacials into early glacial conditions (MISs 5d-5a) but then collapses (or even reverses) during (peak) glacials (Figures 2d and 4). 


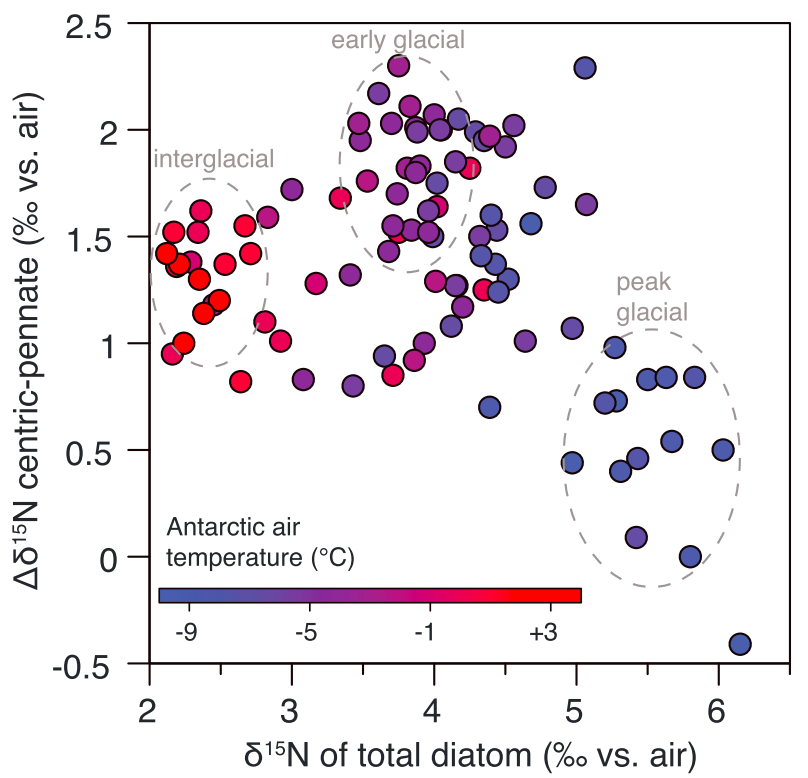

Figure 4. Centric-pennate $\delta^{15} \mathrm{~N}_{\mathrm{db}}$ difference as a function of total diatom $\delta{ }^{15} \mathrm{~N}_{\mathrm{db}}$, color coded according to coincident Antarctic air temperatures reconstructed from ice core $\delta \mathrm{D}$ (Figure 2). The centric-pennate $\delta{ }^{15} \mathrm{~N}_{\mathrm{db}}$ difference increases into the early glacial (purple points), followed by a decline into the peak glacial (blue points). Deglacial points have been omitted (Figure S4 in the supporting information).
Noteworthy are the early stages of the deglaciations, where centric $\delta^{15} \mathrm{~N}_{\mathrm{db}}$ remains high as total diatom and pennate $\delta^{15} \mathrm{~N}_{\mathrm{db}}$ start to decline. Despite their distinct $\mathrm{N}$ isotopic signatures, both the centric and pennate assemblages record the $\delta^{15} \mathrm{~N}_{\mathrm{db}}$ elevation into the ice ages.

\subsection{Biogenic Fluxes}

Export production as inferred from $\mathrm{Ba} / \mathrm{Fe}$ and ${ }^{230} \mathrm{Th}$-normalized opal flux is higher during interglacials and lower during the ice ages (Figures 2e and 2f), consistent with other proxy evidence from the Southern Ocean, indicating reduced $A Z$ export production during glacial periods [Mortlock et al., 1991; François et al., 1997; Kohfeld et al., 2005; Jaccard et al., 2013]. During the warm periods of MIS 5 (MISs $5 a, 5 c$, and 5e), opal flux shows three apparently precessional peaks of similar amplitude, with MISs $5 \mathrm{a}$ and $5 \mathrm{c}$ reaching fluxes equivalent to those of MIS $5 e$, the penultimate peak interglacial. While $\mathrm{Ba} / F e$ suggests a similar deglacial increase in export production during terminations I and II, opal flux indicates that Holocene rates were roughly half of those of MIS 5, an observation for which we offer no explanation. Opal flux is high throughout the Holocene, in contrast to previous observations from the Atlantic AZ that indicate highest opal fluxes during the deglaciation [Anderson et al., 2009].

\subsection{Diatom Species Abundance}

Reported are the 11 most abundant diatom species present in core PS75/072-4, representing $>90 \%$ of the diatom assemblage. The pennate diatoms dominate the total diatom assemblage throughout the record, with abundances ranging from $60 \%$ during peak glacials to $90 \%$ during peak interglacials (Figure 5, red colors). The centric assemblage shows the opposite pattern, with up to $35 \%$ abundance during peak glacials and $\sim 10 \%$ during peak interglacials (Figure 5 , green colors). The pennate assemblage is dominated by F. kerguelensis ( 70-90\%), with minor contributions of other Fragilariopsis species (F. separanda, F. curta, and F. rhombica) and Thalassiothrix antarctica. The centric assemblage is dominated by T. lentiginosa $(\sim 30-80 \%)$, with contributions from Chaetoceros spp., T. gracilis, E. antarctica, A. tabularis, and T. trifulta. While diatom counts are useful to determine the species composition and relative abundance, we note here that they do not translate into opal biovolume [Hillebrand et al., 1999].

\section{Interpretation and Discussion}

\subsection{Implications of Assemblage $\delta^{15} \mathrm{~N}_{\mathrm{db}}$ for Total Diatom $\delta^{15} \mathrm{~N}_{\mathrm{db}}$}

While the differences among total diatom, pennate, and centric $\delta^{15} \mathrm{~N}_{\mathrm{db}}$ will be discussed further in a section below, most of the major changes are shared among the three records. Most importantly, ice age $\delta^{15} \mathrm{~N}_{\mathrm{db}}$ elevation is also observed in both of the separated diatom assemblages (Figure 2d), indicating that each contributes to the observed ice age elevation of the $\delta^{15} \mathrm{~N}_{\mathrm{db}}$ of the total diatom fraction (although we reiterate that the pennate fraction dominates the total diatoms). Moreover, the $\delta^{15} \mathrm{~N}_{\mathrm{db}}$ difference between the fractions in any given interval is less than the full amplitude of the $\mathrm{G} / \mathrm{IG}$ change in the $\delta^{15} \mathrm{~N}_{\mathrm{db}}$ of total diatoms, such that even a complete shift from one assemblage to another (had it occurred) could not drive the G/IG change in the $\delta^{15} \mathrm{~N}_{\mathrm{db}}$ of total diatoms. The three data sets 


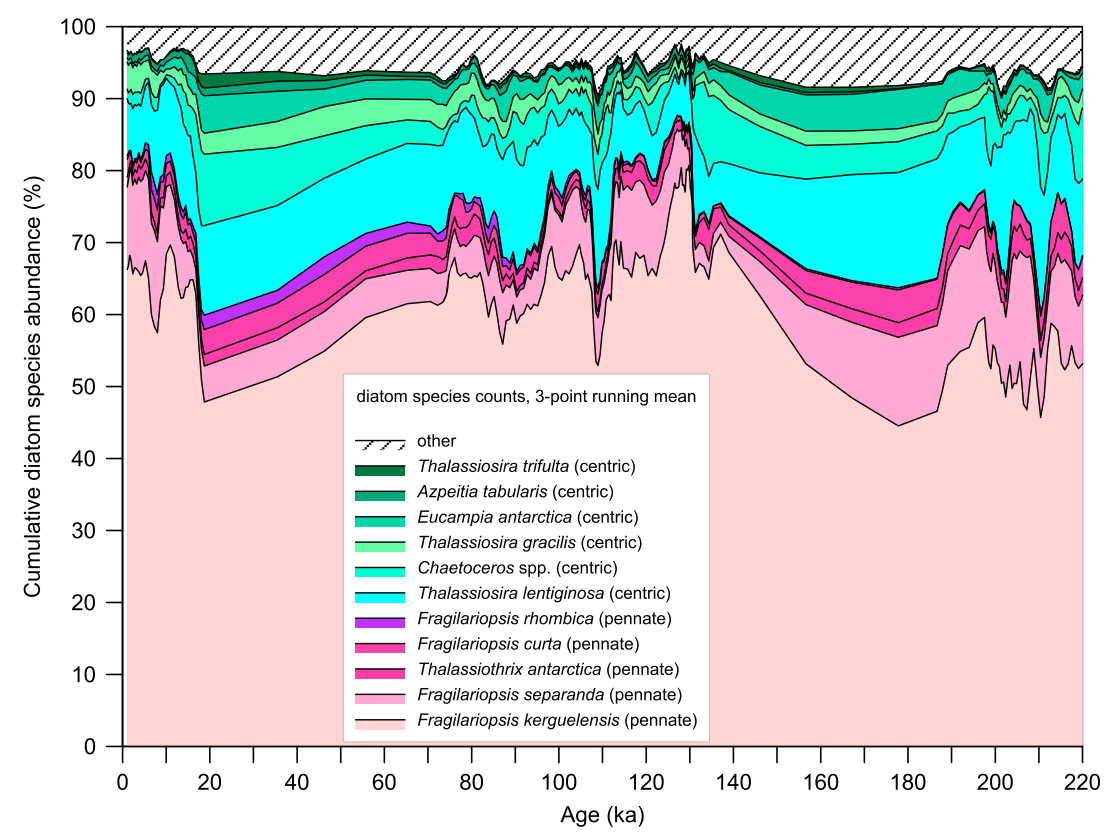

Figure 5. Diatom species counts in sediment core PS75/072-4. The diatom species are grouped into pennates and centrics and arranged from bottom up in order of decreasing abundance. Reported are the 11 most abundant diatom species present in core PS75/072-4, representing $>90 \%$ of the diatom assemblage. Pennate diatoms are pink-purple colored, centric diatoms blue-green. Fragilariopsis kerguelensis dominates the total diatom assemblage $(\sim 40-80 \%)$, followed by Thalassiosira lentiginosa $(\sim 5-20 \%)$. The pennate assemblage is dominated by F. kerguelensis ( 70-90\%), with minor contributions of other Fragilariopsis species (F. separanda, F. curta, and F. rhombica) and Thalassiothrix antarctica. The centric assemblage is dominated by T. lentiginosa ( 30-80\%), with contributions of Chaetoceros spp., T. gracilis, E. antarctica, A. tabularis, and T. trifulta.

together thus rule out the possibility that the changes in total diatom $\delta^{15} \mathrm{~N}_{\mathrm{db}}$ are an artifact of changes between these two diatom assemblages.

Through the record, we observe correlations between $\delta^{15} \mathrm{~N}_{\mathrm{db}}$ and some diatom species (Figure 5 and Figure S2 in the supporting information). This is to be expected since both types of measurements show clear $\mathrm{G} / \mathrm{IG}$ changes; no direct causative link between $\delta^{15} \mathrm{~N}_{\mathrm{db}}$ and diatom species changes is required. However, a direct causative link has been suggested in previous studies, with diatom species changes directly driving $\delta^{15} \mathrm{~N}_{\mathrm{db}}$ change [Jacot des Combes et al., 2008], and so we address this possibility here. The more abundant species partition relatively purely into either the pennate or centric assemblage fractions and would have thus not affected the $\delta^{15} \mathrm{~N}_{\mathrm{db}}$ of all of the diatom fractions in a similar way. It is theoretically possible that there exists a rare diatom species that occurs equally in the pennate and centric assemblages, has a particularly characteristic $\delta^{15} \mathrm{~N}_{\mathrm{db}}$, and thus drives the $\delta^{15} \mathrm{~N}_{\mathrm{db}}$ changes in both assemblages and the total diatoms. Chaetoceros spp. and Eucampia antarctica may not sort strongly into either of the separated diatom fractions. Both species increase in a proportionally significant way during ice ages, such that their abundance shows a strong correlation with $\delta^{15} \mathrm{~N}_{\mathrm{db}}\left(R^{2}>0.3\right)$. One might then propose that changes in the importance of these species drive the $\delta^{15} \mathrm{~N}_{\mathrm{db}}$ of each measured fraction. However, even a $20 \%$ increase in these two species during glacials (which is never observed in this core) cannot explain the $\sim 3.5 \%$ glacial $\delta^{15} \mathrm{~N}_{\mathrm{db}}$ increase of the total diatom fraction, as this would require them to have an unrealistically high $\delta^{15} \mathrm{~N}_{\mathrm{db}}, \sim 17 \%$ higher than the remaining $80 \%$ of the diatom fraction. Thus, the assemblage level $\delta^{15} \mathrm{~N}_{\mathrm{db}}$ measurements and diatom species data combine to indicate that diatom species changes alone cannot explain the $\delta^{15} \mathrm{~N}_{\mathrm{db}}$ changes.

These issues aside, the G/IG changes in diatom species may hold information regarding upper ocean environmental conditions that could allow for a better mechanistic understanding of the physical and biogeochemical changes reconstructed with $\delta^{15} \mathrm{~N}_{\mathrm{db}}$ and export production proxies. The most quantitatively significant diatom species change is that the abundance of centric diatoms, dominated by $T$. lentiginosa, increases from $\sim 15 \%$ during interglacials to $\sim 30 \%$ during peak ice ages, increasing relative to the pennates, 


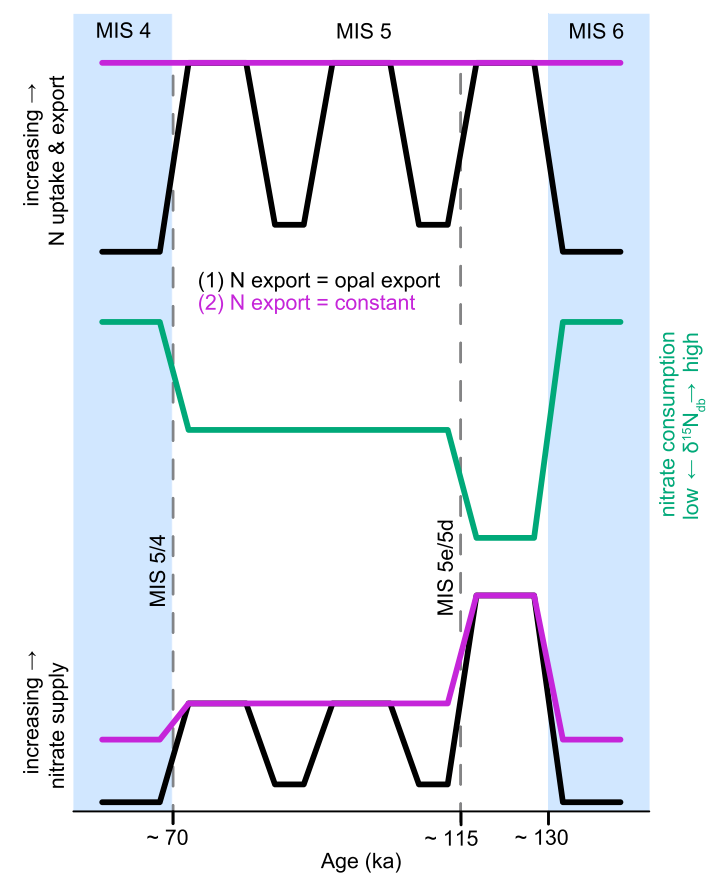

Figure 6. Schematic reconstruction of the rate of gross nitrate supply to the AZ surface from MIS 6 to MIS 4 from histories of the degree of nitrate consumption (as indicated by (middle) $\delta^{15} \mathrm{~N}_{\mathrm{db}}$ ) and of nitrate uptake rate (as indicated by (top) opal flux). In the calculation, the gross nitrate supply equals export production divided by the degree of nitrate consumption (1) following (in stylized form) the changes in biogenic opal flux Given that neither scenario allows for increases in nitrate uptake rate at the MIS $5 \mathrm{e} / 5 \mathrm{~d}$ or MIS 5/4 transitions, the rise in the degree of nitrate consumption requires that nitrate supply decreased during both time intervals (bottom), given the observed $\delta{ }^{15} \mathrm{~N}_{\mathrm{db}}$ increases during those times. (equation (1)). Two scenarios are shown for nitrate uptake rate: (black), or (2) constant, for the sake of comparison (purple).

which are dominated by $F$. kerguelensis. In greater detail, the $T$. lentiginosa-to- $F$. kerguelensis ratio appears to covary with the opal flux changes within MIS 5 (Figure S3 in the supporting information), suggesting a stronger tie to opal flux than to $\delta^{15} \mathrm{~N}_{\mathrm{db}}$. Shemesh et al. [1989] find that T. lentiginosa has higher dissolution resistance than $F$. kerguelensis. Thus, the rise in the $T$. lentiginosa-to- $F$. kerguelensis ratio during the ice ages is best explained as the result of reduced opal preservation under low opal fluxes to the seabed-an expected result [Hurd, 1973; Nelson et al., 1995].

Changes in the less abundant diatoms may speak to biogeochemical changes. The frustules of $E$. antarctica and Chaetoceros spp. found in the sediment are both resting spore/winter stages that form under conditions unfavorable for growth, and nitrate depletion has specifically been noted for Chaetoceros [Leventer, 1991, and references therein]. The increase of Chaetoceros resting spores up to $>10 \%$ during glacial maxima may thus provide an additional piece of evidence for the nitrate depletion that is inferred from the peak glacial $\delta^{15} \mathrm{~N}_{\mathrm{db}}$ data (see below).

\subsection{Reduced Gross Nitrate Supply to $A Z$ Surface During Glacials}

In high-latitude HNLC regions such as the Antarctic Zone of the Southern Ocean, the isotopic composition of exported $\mathrm{N}$ records the fraction of the gross nitrate supply that is consumed (or "utilized" [Altabet and François, 1994]):

$$
C=U / S
$$

where $C$ is the degree of nitrate consumption in the surface mixed layer; $U$ is the rate of nitrate uptake by phytoplankton, which is assumed to eventually lead to $\mathrm{N}$ export and which occurs predominantly in the spring/summer; and $S$ is the gross rate of nitrate supply to the surface mixed layer. The $\delta^{15} \mathrm{~N}_{\mathrm{db}}$ presented here indicate that nitrate consumption was consistently more complete in the $A Z$ ( $C$ was higher) during glacial periods, while export production was lower ( $U$ was lower). This combination requires a decline in $S$, the supply rate of nitrate to the surface ocean.

Focusing on the last glacial cycle, the $\delta^{15} \mathrm{~N}_{\mathrm{db}}$ data suggest that $C$ increased primarily at the MIS 5e/5d and the MIS 5/4 transitions (Figure 2). The two proxies of export production do not yield identical histories here, and the opal flux record in particular has a significantly different structure than the $\delta^{15} \mathrm{~N}_{\mathrm{db}}$ record, with no permanent decline at the MIS $5 \mathrm{e} / 5 \mathrm{~d}$ transition but rather a set of three peaks that may be linked to precession (i.e., with maxima during MISs 5e, 5c, and 5a). We suspect that this pattern involves changes in the nutrient content of the source water supplied to this site, as modulated by North Atlantic Deep Water formation changes (see below). However, we will address this question elsewhere, with the benefit of additional data.

Rather, we focus here on the significance of the export production data for the G/IG reconstruction of gross nitrate supply rate to the $A Z$ surface. For the sake of argument, we undertake a calculation of changes in nitrate supply rate using simplified reconstructions of $C$ and $U$ based on $\delta^{15} N_{d b}$ and biogenic opal flux, respectively (Figure 6). To clarify the role of the reconstructed export production in this calculation, two different scenarios are assumed for export production and thus $U$ : one where $\mathrm{N}$ export is proportional 
toreconstructed thorium-normalized opal accumulation (Figure 6, black line in top plot) and one where $\mathrm{N}$ export is constant (Figure 6 , purple line in top plot). Regardless of which $\mathrm{N}$ export scenario is assumed across MIS 6 to MIS 4, increasing degree of nitrate consumption requires that the rate of nitrate supply declined at both the MIS $5 e / 5 d$ and MIS $5 / 4$ transitions. Thus, while the changes in export production over the early portion of the last glacial cycle (MIS $5 \mathrm{~d}$ to MIS $5 \mathrm{a}$ ) and their causes remain unclear, the combined export production and $\delta^{15} \mathrm{~N}_{\mathrm{db}}$ data suggest that the gross nitrate supply to the Antarctic Zone surface was depressed over the entire extent of the last ice age (from MIS $5 d$ to MIS 2).

A change in the physical circulation must have reduced the gross supply of nitrate into the surface-mixed layer during glacial times by reducing the gross transport of interior (i.e., deep) water into the AZ surface. Following previous work, we refer to this reduced gross supply of deep water to the surface as "stratification" [François et al., 1997; Sigman et al., 2004]. Today, nitrate is supplied to the core site largely from Upper Circumpolar Deep Water (UCDW) by Ekman upwelling and vertical mixing, with Lower Circumpolar Deep Water (LCDW) possibly contributing by vertical mixing further to the south followed by lateral exchange [DiFiore et al., 2010]. The data in hand cannot as yet distinguish which nitrate supply mechanism-wind-driven upwelling or vertical mixing-decreased during ice ages, as these two processes interact [Toggweiler et al., 2006; de Boer et al., 2007].

Early explanations for the ice age reduction in biogenic fluxes in the AZ involved increased restrictions on phytoplankton growth by light or temperature, as might result from summer sea ice cover or deep summer mixed layers, for example. This set of explanations clearly violates the data reported here, as these changes would have led to a lower degree of nitrate consumption and thus lower, not higher, $\delta^{15} \mathrm{~N}_{\mathrm{db}}$. Below, we address the possible mechanisms behind the ice age increase in the degree of nitrate consumption.

\subsection{The Control of Iron Versus Light on Nitrate Uptake}

The low degree of nitrate consumption (i.e., the low ratio of nitrate uptake relative to the gross nitrate supply from below) in the modern Southern Ocean has been explained by the scarcity of iron [Martin et al., 1990], light [Mitchell et al., 1991], or both [Sunda and Huntsman, 1997]. In order for the degree of nitrate consumption to increase during glacial times, the limiting factor on phytoplankton growth must have been alleviated relative to the nitrate supply.

Deep waters have a deficit in iron relative to nitrate [Johnson et al., 1997]. A sharp ice age reduction in nutrient supply from below, especially given the apparent increase in atmospheric iron sources [Lambert et al., 2008; Martínez-García et al., 2009; Lamy et al., 2014], should have increased the iron-to-nitrate supply ratio to AZ phytoplankton, causing nitrate consumption to become more complete (Figure 7a).

A class of explanations for increased nitrate consumption different from these related to iron involves the relaxation of light limitation as a result of reduced vertical mixing, allowing the summer mixed layer to shoal. However, an intermediate degree of nitrate consumption coupled with similar or reduced export production, such as is observed in the early glacial (MISs 5a-5d) [Jaccard et al., 2013] (Figure 2), cannot be explained as the relief of summertime light limitation. If light were the only limiting factor, easing its limitation would lead to an increase in export production (scenario 2 in Figure 7b), which is contrary to observations. If the glacial state is accompanied by a reduction in the nitrate $\left(\left[\mathrm{NO}_{3}{ }^{-}\right]\right)$supply, then export production could decrease (consistent with observations) only if nitrate is consumed to completion (scenario 1 in Figure 7b), counter to early glacial observations. Thus, the data for early glacial biogeochemical conditions argue against pure light limitation and for iron limitation as the dominant control on summertime Antarctic phytoplankton growth. Iron/light colimitation could be consistent with the data, with improved light conditions effectively lowering the iron requirement of phytoplankton.

\subsection{The $\delta^{15} \mathrm{~N}_{\mathrm{db}}$ Changes Through the Last Ice Age}

Emanating from the peak warmth of the penultimate interglacial period (Figure 8a), the first apparent $\delta^{15} \mathrm{~N}_{\mathrm{db}}$ increase occurs at the MIS 5e/5d transition ( 115 ka), in the face of decreasing or stable export production and in the absence of a substantial increase in dust input to Antarctica [Lambert et al., 2008] (Figure 2) and the Southern Ocean [Martínez-García et al., 2011]. This implies that the increase in the degree of nitrate consumption was related to a decrease in the supply of major nutrients, which supports the previously postulated idea that the Antarctic Zone of the Southern Ocean stratified at the MIS $5 \mathrm{e} / 5 \mathrm{~d}$ transition 


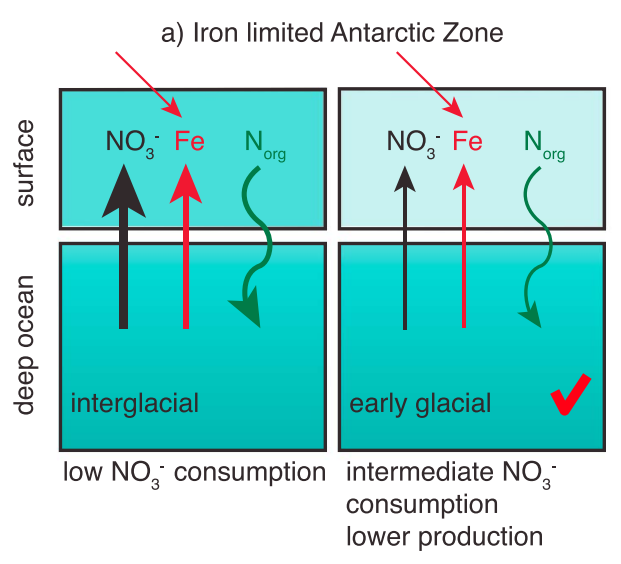

b) Light limited Antarctic Zone
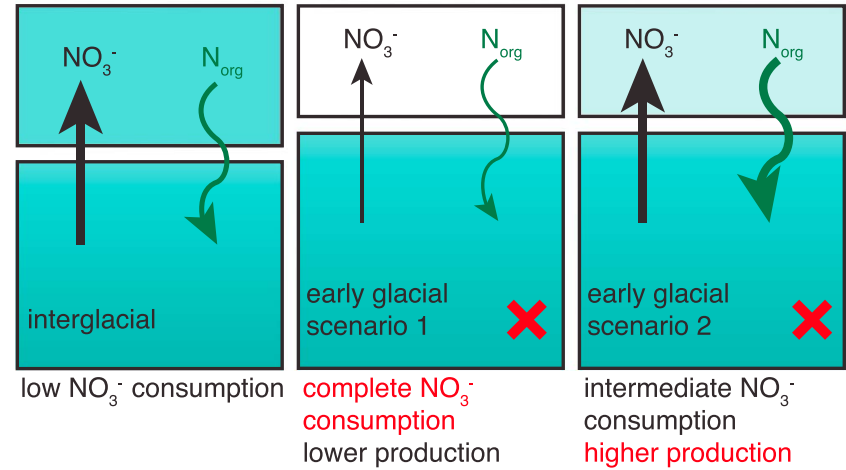

Figure 7. The effects of relaxation of iron and light limitation in the glacial $A Z$ on nitrate consumption and export production. (a) A glacial increase in stratification will reduce the supply of both $\left[\mathrm{NO}_{3}{ }^{-}\right.$] and Fe to the surface $\mathrm{AZ}$, reducing export production. The additional $\mathrm{Fe}$ input from dust will increase the $\mathrm{Fe}: \mathrm{NO}_{3}{ }^{-}$supply ratio, such that nitrate consumption will increase relative to the interglacial scenario, consistent with observations (Figure 2). (b) A glacial shoaling of the mixed layer will improve light conditions for phytoplankton. If light were the only limiting factor, this should lead to an increase in export production (scenario 2), which is contrary to observations. If the glacial state is accompanied by a reduction in the $\left[\mathrm{NO}_{3}{ }^{-}\right]$supply, then export production could decrease (consistent with observations) only if nitrate is consumed to completion (scenario 1), counter to early glacial observations. Thus, neither scenario for relief of light limitation simultaneously matches the $\delta^{15} \mathrm{~N}_{\mathrm{db}}$ and export production proxy constraints.

[Hain et al., 2010] (Figure 8b). A stratified AZ surface ocean would have reduced evasion of $\mathrm{CO}_{2}$ to the atmosphere, both by decreasing the preformed nutrient content of the waters with which the AZ ventilated the ocean interior and by decreasing the relative importance of the $A Z$ as a ventilator of the global ocean interior. Both of these changes would have raised the efficiency of the global biological pump and can explain the $40 \mathrm{ppm}$ decrease in atmospheric $\mathrm{CO}_{2}$ associated with the MIS 5e/5d transition [Lüthi et al., 2008; Hain et al., 2010].

In contrast, the second $\delta^{15} \mathrm{~N}_{\mathrm{db}}$ rise at the MIS 5/4 transition ( $\left.70 \mathrm{ka}\right)$ is associated with a significant increase in atmospheric iron deposition in the Subantarctic Zone of the Southern Ocean [Martínez-García et al., 2009; Anderson et al., 2014], Antarctic ice cores [Lambert et al., 2008], and possibly at this site in the Pacific AZ. Iron fertilization of the Subantarctic starting at the MIS 5/4 transition has been proposed to account for the second major drop in atmospheric $\mathrm{CO}_{2}$ [Martínez-García et al., 2014; Jaccard et al., 2013; Kohfeld et al., 2005; Hain et al., 2010, and references therein]. However, at our core site and throughout the AZ, there is no evidence for increased export production upon the MIS 5/4 transition, arguing that if the increased atmospheric iron supply was felt in the $A Z$, its effect on export production was offset by other processes. The rise in $\delta^{15} \mathrm{~N}_{\mathrm{db}}$ and apparent further decline in export production may be explained by a further reduction in surface/deep exchange in the Antarctic Zone. In addition, there is significant lateral mixing across the Polar Frontal Zone [DiFiore et al., 2006], such that Subantarctic Zone nutrient conditions might impact surface nitrate concentrations in the northernmost Antarctic Zone, just to the south of the polar front. It appears that iron fertilization led to more complete nitrate consumption in the Subantarctic Zone 
a) Marine Isotope Stage $5 \mathrm{e}$ (interglacial)

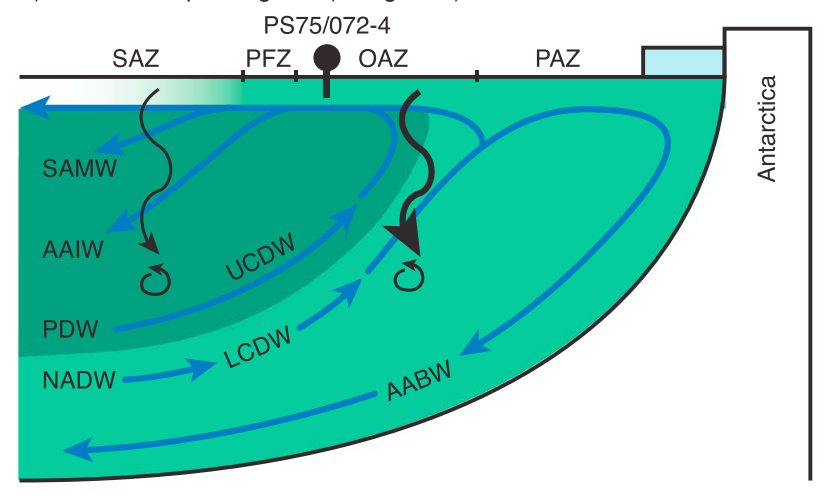

b) Marine Isotope Stage 5d ("early glacial")

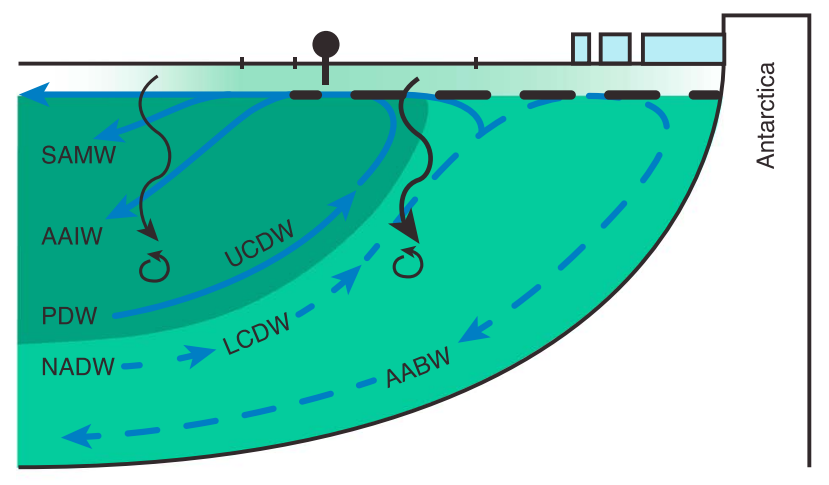

c) Marine Isotope Stage 4 (glacial)

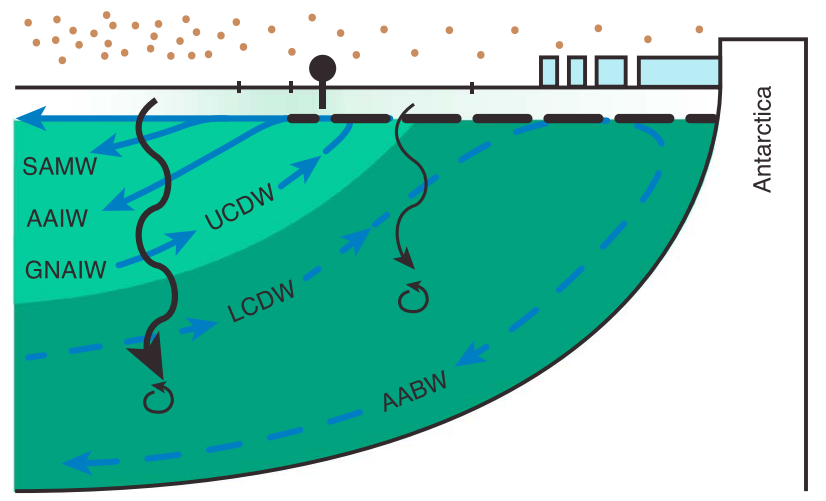

Figure 8. Schematic section of the Southern Ocean at different stages through the glacial progression with interpreted changes in circulation, nitrate concentration, and Antarctic stratification. (a) Interglacial MIS 5e, (b) early glacial MISs 5d-5a, and (c) glacial MIS 4. The green shading indicates nitrate concentration, with darker shades representing higher $\left[\mathrm{NO}_{3}{ }^{-}\right]$. (Figure 8a) During peak interglacial MIS 5e, nitrate-rich UCDW is upwelled to the core site, leading to high productivity and a low degree of nitrate consumption. (Figure $8 \mathrm{~b}$ ) At the MIS $5 \mathrm{e} / 5 \mathrm{~d}$ transition, a decrease in the gross supply of deep water to the $A Z$ surface reduces export production and increases the degree of nitrate consumption. (Figure 8c) At the MIS 5/4 transition, two possible scenarios may have lead to a further decline in gross nitrate supply: (1) further reduction in surface/deep communication and/or (2) a drop in the nitrate concentration of UCDW as a result of both iron fertilization in the SAZ and a shoaling of NADW to GNAIW. SAZ = Subantarctic Zone; PFZ = Polar Frontal Zone; AZ = Antarctic Zone; OAZ = Open Antarctic Zone; PAZ = Polar Antarctic Zone; SAMW = Subantarctic Mode Water; AAIW = Antarctic Intermediate Water, PDW = Pacific Deep Water; UCDW = Upper Circumpolar Deep Water; LCDW = Lower Circumpolar Deep Water; NADW = North Atlantic Deep Water; GNAIW = Glacial North Atlantic Intermediate Water; AABW = Antarctic Bottom Water. Water mass transport (dashed line represents more sluggish circulation) (blue arrows). Export production (black wavy arrows). Remineralization (black circling arrows). Reduced water exchange between surface waters and underlying deep water ("stratification") (black dashed line). Core site (black dot). Dust (iron) deposition (brown dots). 
starting at the MIS 5/4 transition [Martínez-García et al., 2014]. This may have diluted surface nitrate at our core site, effectively decreasing $S$ in equation (1) and thus allowing a higher degree of nitrate consumption for a given rate of nitrate assimilation. This suggestion could be tested with cores from farther south in the $A Z$, as the impact of mixing with the SAZ should not reach far into the $A Z$.

Large-scale ocean changes may have also played a role in the MIS 5/4 biogeochemical changes. Two such changes are suspected to have shifted nutrients out of the middepth ocean and into the abyss at this time, thus decreasing the nutrient supply to the open AZ. The first was the Subantarctic iron fertilization noted above, which would have prevented unused nitrate from passing through the Southern Ocean and into intermediate and thermocline depths of the global ocean [Keir, 1988]. Second, the MIS 5/4 transition is believed to be the time when the North Atlantic Deep Water shoaled to form Glacial North Atlantic Intermediate Water (GNAIW) [Hodell et al., 2003; Piotrowski et al., 2005, 2009; Guihou et al., 2011]. It is expected, with support from observations, that both of these changes led regenerated nutrients and carbon from the downward rain of organic matter to be shifted from middepths into the abyssal ocean [Boyle, 1988; Keir, 1988; Toggweiler, 1999], complementarily depleting GNAIW and the downstream middepth Indo-Pacific of nutrients. UCDW is upwelled at our core site, and it derives from roughly $2 \mathrm{~km}$ depth in the low latitudes (Figure 1b). As this was the approximate depth of GNAIW, Subantarctic iron fertilization and the NADW-to-GNAIW shift may have lowered the nitrate concentration of UCDW and thus reduced the nitrate supply to our core site (Figure $8 \mathrm{c}$ ). Such a change should cause an increase in the degree of nitrate consumption (by decreasing $S$ in equation (1)) and thus may explain part of the $\delta^{15} \mathrm{~N}_{\mathrm{db}}$ rise at the MIS 5/4 transition. The relationship of these changes to the decline in export production is highly uncertain, depending on how the iron concentration of UCDW changed in response to the proposed changes in its major nutrient concentrations. If the iron concentration of UCDW did not decrease in step with its major nutrient concentrations, then the decline in export production would require a further shift toward stratification at the MIS 5/4 transition (Figure 8c).

The cause of the third and more gradual rise in $\delta^{15} \mathrm{~N}_{\mathrm{db}}$ into the LGM is particularly difficult to pose specific hypotheses for, partly because many climate and biogeochemical parameters show extrema during the LGM and partly because age control is weakest in the sediments of MIS 4 to MIS 2.

\subsection{Environmental Significance of the $\delta^{15} \mathrm{~N}_{\mathrm{db}}$ Difference Between Centric and Pennate Diatom Assemblages}

The overall trends among total diatom, pennate, and centric $\delta{ }^{15} \mathrm{~N}_{\mathrm{db}}$ are very similar, such that most of the temporal total diatom $\delta^{15} \mathrm{~N}_{\mathrm{db}}$ changes that were discussed above also apply to the pennate and centric $\delta^{15} \mathrm{~N}_{\mathrm{db}}$. Nevertheless, there are differences among the records that warrant consideration. With the benefit of the diatom species information collected accompanying the $\delta^{15} \mathrm{~N}_{\mathrm{db}}$ data, we provide a tentative interpretation for the $\mathrm{N}$ isotopic difference between the centric and pennate-rich diatom fractions.

The $\delta{ }^{15} \mathrm{~N}_{\mathrm{db}}$ difference that characterizes the centric and pennate diatom assemblages may indicate (1) a difference in seasonality or depth habitat, as it affects the $\delta^{15} \mathrm{~N}$ of the available nitrate, (2) differences in the dominant form of $\mathrm{N}$ assimilated (i.e., nitrate or recycled ammonium) [Fawcett et al., 2011], or (3) physiological differences that result in a different $\delta^{15} \mathrm{~N}_{\mathrm{db}}$ /diatom biomass $\delta^{15} \mathrm{~N}$ relationship [Horn et al., 2011; Morales et al., 2013]. Regarding the last, if the centric-pennate $\delta^{15} \mathrm{~N}_{\mathrm{db}}$ difference were solely due to differences in fundamental biosynthesis pathways as they impact the $\delta^{15} \mathrm{~N}$ relationship between the biomass $\mathrm{N}$ of a diatom and its frustule-bound $\mathrm{N}$, then a constant interassemblage difference would be expected over time. Instead, the coherent covariation of the centric-pennate $\delta^{15} \mathrm{~N}_{\mathrm{db}}$ difference with climate, with a larger offset during warm periods and almost no offset during peak glacials (Figure 2), suggests that it reflects environmental change.

The Antarctic Zone of the Southern Ocean is characterized by a seasonal cycle of nitrate recharge in the winter that is followed by nitrate uptake during the subsequent spring and summer, leading to an increase in nitrate $\delta^{15} \mathrm{~N}$ over the course of the season (Figure 9). It is possible that the diatom assemblages record different periods in the seasonal progression. In this case, the higher $\delta^{15} \mathrm{~N}_{\mathrm{db}}$ of the centric diatoms, which represent a secondary fraction of the total diatom material (Figure 5), could be explained if they reach greatest proportional importance (relative to other species) in middle to late summer, a tendency that 


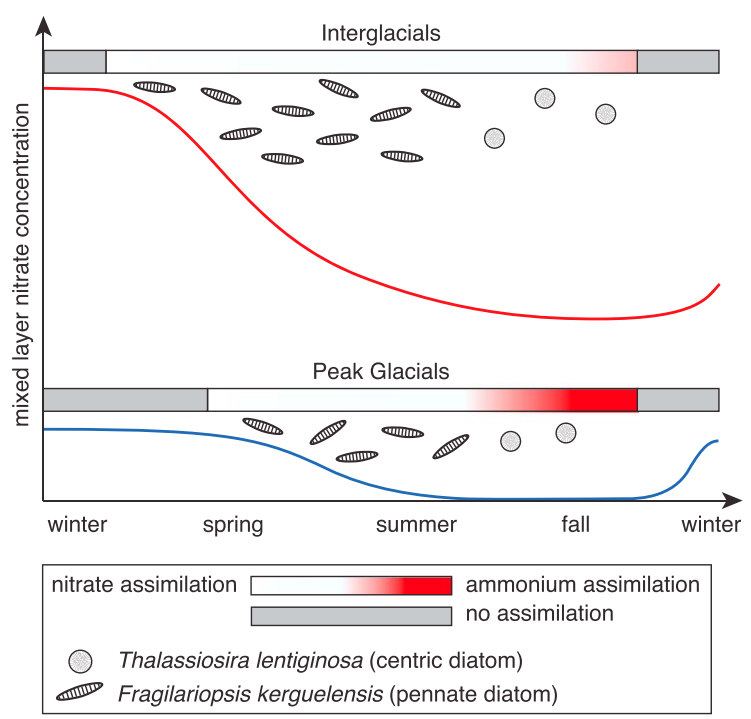

Figure 9. Inferred AZ surface nitrate seasonality during interglacials and peak glacials and its proposed role in explaining the convergence of pennate and centric $\delta^{15} \mathrm{~N}_{\mathrm{db}}$ during peak glacials. The red and blue lines represent the nitrate concentration during interglacials and peak glacials, respectively. The Antarctic Zone of the Southern Ocean is characterized by a seasonal cycle of nitrate recharge in winter that is followed by nitrate uptake during the subsequent spring and summer. Because of more vigorous wintertime recharge, spring nitrate concentrations are higher during interglacials compared to glacials, and nitrate is never drawn down completely by the end of the growth season, such that nitrate and recycled low- $\delta{ }^{15} \mathrm{~N}$ ammonium are both utilized by diatoms in the later summer. During peak glacials, spring nitrate concentrations are lower, such that the AZ becomes nitrate free by the later summer, leaving late season diatom growth to rely primarily on the low- $\delta{ }^{15} \mathrm{~N}$ ammonium being continuously produced by upper ocean $\mathrm{N}$ recycling. Given the proposal that centric diatoms are biased toward growth in the middle to late summer, this would provide an explanation for the convergence of pennate and centric diatom $\delta{ }^{15} \mathrm{~N}_{\mathrm{db}}$ during peak glacials (e.g., the LGM). is arguably (although not convincingly) supported by existing observations from net tow and sediment trap studies [Fischer et al., 2002; Armand et al., 2008].

During the early glacial (MISs $5 a-5 d$ ), the $\delta^{15} \mathrm{~N}_{\mathrm{db}}$ difference between the centric and pennate fractions almost doubled relative to their interglacial difference (Figure 4). Total diatom $\delta^{15} \mathrm{~N}_{\mathrm{db}}$ points to a rise in degree of nitrate consumption during this time, and this is explained by reduced nitrate supply, higher iron-to-nitrate supply ratio, and possibly improved summer light conditions due to mixed layer shoaling. Under these conditions, the proportional nitrate drawdown over the summer should have risen, and this would yield a larger summertime change (increase) in mixed layer nitrate $\delta^{15} \mathrm{~N}$. In the case of the proposed bias of the centric diatoms to middle to late summer, the observed increase in centric-pennate $\delta^{15} \mathrm{~N}_{\mathrm{db}}$ difference can be explained by this greater summertime nitrate $\delta{ }^{15} \mathrm{~N}$ increase.

However, during peak ice ages, the centricpennate $\delta^{15} \mathrm{~N}_{\mathrm{db}}$ difference is observed to decline sharply (Figure 4). Given the discussion above, this change is inconsistent with the expectations based on the summertime evolution of nitrate $\delta^{15} \mathrm{~N}$ of an even greater centric-pennate $\delta^{15} \mathrm{~N}_{\mathrm{db}}$ difference. We speculate that the peak glacial decline in the centric-pennate $\delta^{15} \mathrm{~N}$ difference is an indication that in this region of the $A Z$ during peak glacials, nitrate was completely consumed by late summer. The logic is as follows.

If nitrate were the only $\mathrm{N}$ source available for phytoplankton assimilation in the modern Southern Ocean, then the $\delta^{15} \mathrm{~N}$ of their organic matter should increase over the course of the spring and summer. However, modern ocean data indicate that surface suspended particulate nitrogen (PN) $\delta^{15} \mathrm{~N}$ actually decreases during late austral summer (February/March) [Lourey et al., 2003]. This has been explained as the result of enhanced summertime ammonium recycling in the euphotic zone. Heterotrophy in surface waters tends to preferentially export high $\delta^{15} \mathrm{~N}$ organic $\mathrm{N}$ from the surface ocean, releasing back into the mixed layer low- $\delta^{15} \mathrm{~N}$ ammonium that is quickly reconsumed by phytoplankton, leading to a decline in surface suspended $\mathrm{PN} \delta{ }^{15} \mathrm{~N}$ [Altabet, 1988]. Thus, throughout the summer period, heterotrophy is inferred to supply low- $\delta^{15} \mathrm{~N}$ ammonium to the phytoplankton population. This ammonium never accumulates to high concentrations (although it can reach $\geq 1 \mu \mathrm{M}$ in Antarctic waters [Tréguer and Jacques, 1992]). This reflects the fact that the ammonium is assimilated roughly at the same rate as it is produced by heterotrophy and remineralization.

Relative to cyanobacteria, eukaryotic phytoplankton are observed to have a greater reliance on nitrate [Fawcett et al., 2011, and references therein] (i.e., a greater " $f$ ratio" as defined by Eppley and Peterson [1979]). Diatoms in particular appear to have a strong tendency toward nitrate assimilation [Dortch, 1990; Savidge et al., 1995; Goericke, 2002; Fawcett and Ward, 2011]. One explanation for the higher $\delta^{15} \mathrm{~N}$ of the centric diatom assemblage during interglacials is that the centric and pennate diatoms consume nitrate and ammonium in similar ratios, such that the summertime rise in nitrate $\delta^{15} \mathrm{~N}$ is imprinted on the $\delta^{15} \mathrm{~N}_{\mathrm{db}}$ difference between 
the two assemblages despite the availability of $l o w-\delta{ }^{15} \mathrm{~N}$ ammonium throughout the growth period. Alternatively, centrics may consume a greater fraction of ammonium that is nevertheless inadequate to overwhelm the effect of rising nitrate $\delta^{15} \mathrm{~N}$ over the summer.

During peak glacials, however, the total diatom $\delta^{15} \mathrm{~N}_{\mathrm{db}}$ of $\sim 6 \%$ o suggests that summertime nitrate consumption was high and possibly complete. If nitrate consumption did in fact reach completion over the course of each summer, then the diatoms growing in the later summer would have been forced to rely on recycled ammonium (Figure 9). If the centrics are biased toward the middle to late summer, then such a change would work to lower the $\delta^{15} \mathrm{~N}_{\mathrm{db}}$ of the centric assemblage, explaining its convergence with that of the pennate fraction.

One appealing aspect of this proposal is that it could explain why centric $\delta^{15} \mathrm{~N}_{\mathrm{db}}$ does not immediately decline during the deglaciations (Figure 2). As nitrate supply rises and the degree of nitrate consumption falls into the deglaciation, nitrate would once again persist in the mixed layer through the AZ summer. This would decrease the proportional reliance of the middle and late summer centric diatoms on low- $\delta{ }^{15} \mathrm{~N}$ ammonium and thus raise their $\delta^{15} \mathrm{~N}_{\mathrm{db}}$ relative to the pennate fraction. Their absolute $\delta^{15} \mathrm{~N}_{\mathrm{db}}$ may thus have held roughly constant because of offsetting effects from a decline in the degree of nitrate consumption and a concurrent decline in the proportional importance of ammonium assimilation.

The proposal above, in essence, argues for a decoupling of $\delta^{15} \mathrm{~N}_{\mathrm{db}}$ from nitrate consumption at the point of complete nitrate consumption. The reader might interpret this as a major concern for the use of $\delta^{15} \mathrm{~N}_{\mathrm{db}}$ as a general proxy for nitrate consumption. However, it is important to note that total $\delta^{15} \mathrm{~N}_{\mathrm{db}}$ would not be impacted significantly by this effect because it would apply to diatoms growing in the latter part of the growth season, subsequent to nitrate exhaustion: these diatoms will not represent a major proportion of the total diatom production. Thus, while auxiliary fractions of the diatoms may be affected by such nonnitrate dynamics, this is unlikely to dramatically change the outcome for the $\delta^{15} \mathrm{~N}_{\mathrm{db}}$ of total recoverable diatoms.

Of course, there may well be alternative explanations for the peak glacial collapse in the centric-pennate $\delta^{15} \mathrm{~N}_{\mathrm{db}}$ difference. With low rates of nitrate supply and high degrees of nitrate consumption, the nature of upper ocean nitrate $\delta^{15} \mathrm{~N}$ may differ in dramatic ways from the modern condition. Numerical simulations are required to understand and quantify such potential changes. More broadly, as paleogeochemical studies begin to explore the differences among different diatom groups and species, modern ocean data on the ecology and biogeochemistry of diatoms at the genus and species level are needed.

\section{Acknowledgments}

Data can be downloaded as part of the supplement and will also be made available at www.pangaea.de. We thank the captain and crew of the R/V Polarstern for the recovery of the sediment core during the ANT-XXVI/2 (PS75) cruise to the Southern Ocean. We thank M.A. Weigand and R. Schwarz for their help with laboratory analyses and X. Crosta and M.P. Hain for the discussions. Funding was provided by the Swiss National Science Foundation grant 200021_131886/1 to G.H.H., grant PBEZP2_145695 to A.S.S., grant PZ00P2_142424 to A.M.-G., grant PPOOP2_144811 to S.L.J., by the US NSF grants PLR-1401489, OPP-0612198, and OCE-0992345 to D.M.S., and by the Grand Challenges Program of Princeton University. We thank two anonymous reviewers and the editor, Chris Charles, for their comments, which improved the manuscript.

\section{References}

Ahn, J., and E. J. Brook (2014), Siple Dome ice reveals two modes of millennial $\mathrm{CO}_{2}$ change during the last ice age, Nat. Commun., 5, 3723, doi:10.1038/ncomms4723.

Altabet, M. A. (1988), Variations in nitrogen isotopic composition between sinking and suspended particles: Implications for nitrogen cycling and particle transformation in the open ocean, Deep Sea Res., Part I, 35(4), 535-554.

Altabet, M. A., and R. François (1994), Sedimentary nitrogen isotopic ratio as a recorder for surface ocean nitrate utilization, Global Biogeochem. Cycles, 8(1), 103-116, doi:10.1029/93GB03396.

Anderson, R. F., S. Ali, L. I. Bradtmiller, S. H. H. Nielsen, M. Q. Fleisher, B. E. Anderson, and L. H. Burckle (2009), Wind-driven upwelling in the Southern Ocean and the deglacial rise in atmospheric $\mathrm{CO}_{2}$, Science, 323(5920), 1443-1448.

Anderson, R. F., S. Barker, M. Fleisher, R. Gersonde, S. L. Goldstein, G. Kuhn, P. G. Mortyn, K. Pahnke, and J. P. Sachs (2014), Biological response to millennial variability of dust and nutrient supply in the Subantarctic South Atlantic Ocean, Philos. Trans. R. Soc. London, Ser. A, 372, doi:10.1098/rsta.2013.0054.

Armand, L. K., V. Cornet-Barthaux, J. Mosseri, and B. Quéguiner (2008), Late summer diatom biomass and community structure on and around the naturally iron-fertilised Kerguelen Plateau in the Southern Ocean, Deep Sea Res., Part II, 55(5-7), 653-676.

Bard, E. (1988), Correction of accelerator mass spectrometry ${ }^{14} \mathrm{C}$ ages measured in planktonic foraminifera: Paleoceanographic implications, Paleoceanography, 3(6), 635-645, doi:10.1029/PA003i006p00635.

Barker, S., M. Greaves, and H. Elderfield (2003), A study of cleaning procedures used for foraminiferal Mg/Ca paleothermometry, Geochem. Geophys. Geosyst., 4(9), 8407, doi:10.1029/2003GC000559.

Bereiter, B., D. Lüthi, M. Siegrist, S. Schupbach, T. F. Stocker, and H. Fischer (2012), Mode change of millennial $\mathrm{CO}_{2}$ variability during the last glacial cycle associated with a bipolar marine carbon seesaw, Proc. Natl. Acad. Sci. U.S.A., 109(25), 9755-9760.

Bereiter, B., S. Eggleston, J. Schmitt, C. Nehrbass-Ahles, T. F. Stocker, H. Fischer, S. Kipfstuhl, and J. Chappellaz (2015), Revision of the EPICA Dome $\mathrm{C} \mathrm{CO}_{2}$ record from 800 to 600 kyr before present, Geophys. Res. Lett., 42, 542-549, doi:10.1002/2014GL061957.

Boyle, E. A. (1988), Vertical oceanic nutrient fractionation and glacial interglacial $\mathrm{CO}_{2}$ cycles, Nature, 331(6151), 55-56.

Braman, R. S., and S. A. Hendrix (1989), Nanogram nitrite and nitrate determination in environmental and biological materials by vanadium (III) reduction with chemi-luminescence detection, Anal. Chem., 61(24), 2715-2718.

Brunelle, B. G., D. M. Sigman, M. S. Cook, L. D. Keigwin, G. H. Haug, B. Plessen, G. Schettler, and S. L. Jaccard (2007), Evidence from diatombound nitrogen isotopes for subarctic Pacific stratification during the last ice age and a link to North Pacific denitrification changes, Paleoceanography, 22, PA1215, doi:10.1029/2005PA001205. 
Brunelle, B. G., D. M. Sigman, S. L. Jaccard, L. D. Keigwin, B. Plessen, G. Schettler, M. S. Cook, and G. H. Haug (2010), Glacial/interglacial changes in nutrient supply and stratification in the western subarctic North Pacific since the penultimate glacial maximum, Quat. Sci. Rev., 29(19-20), 2579-2590, doi:10.1016/j.quascirev.2010.03.010.

Casciotti, K. L., D. M. Sigman, M. G. Hastings, J. K. Böhlke, and A. Hilkert (2002), Measurement of the oxygen isotopic composition of nitrate in seawater and freshwater using the denitrifier method, Anal. Chem., 74(19), 4905-4912.

Charles, C. D., P. N. Froelich, M. A. Zibello, R. A. Mortlock, and J. J. Morley (1991), Biogenic opal in Southern Ocean sediments over the last 450,000 years: Implications for surface water chemistry and circulation, Paleoceanography, 6(6), 697-728, doi:10.1029/91PA02477.

de Boer, A. M., D. M. Sigman, J. R. Toggweiler, and J. L. Russell (2007), Effect of global ocean temperature change on deep ocean ventilation, Paleoceanography, 22, PA2210, doi:10.1029/2005PA001242.

DiFiore, P. J., D. M. Sigman, T. W. Trull, M. J. Lourey, K. Karsh, G. Cane, and R. Ho (2006), Nitrogen isotope constraints on subantarctic biogeochemistry, J. Geophys. Res., 111, C08016, doi:10.1029/2005JC003216.

DiFiore, P. J., D. M. Sigman, K. L. Karsh, T. W. Trull, R. B. Dunbar, and R. S. Robinson (2010), Poleward decrease in the isotope effect of nitrate assimilation across the Southern Ocean, Geophys. Res. Lett., 37, L17601, doi:10.1029/2010GL044090.

Dortch, Q. (1990), The interaction between ammonium and nitrate uptake in phytoplankton, Mar. Ecol. Prog. Ser., 61, 183-201.

Dymond, J., E. Suess, and M. Lyle (1992), Barium in deep-sea sediment: A geochemical proxy for paleoproductivity, Paleoceanography, 7(2), 163-181, doi:10.1029/92PA00181.

Eppley, R. W., and B. J. Peterson (1979), Particulate organic matter flux and planktonic new production in the deep ocean, Nature, 282, 677-680.

Fawcett, S. E., and B. B. Ward (2011), Phytoplankton succession and nitrogen utilization during the development of an upwelling bloom, Mar. Ecol. Prog. Ser., 428, 13-31.

Fawcett, S. E., M. W. Lomas, J. R. Casey, B. B. Ward, and D. M. Sigman (2011), Assimilation of upwelled nitrate by small eukaryotes in the Sargasso Sea, Nat. Geosci., 4, 717-722, doi:10.1038/NGEO1265.

Fischer, G., R. Gersonde, and G. Wefer (2002), Organic carbon, biogenic silica and diatom fluxes in the marginal winter sea ice zone and in the Polar Front Region: Interannual variations and differences in composition, Deep Sea Res., Part II, 49(9-10), 1721-1745.

Fleisher, M. Q., and R. F. Anderson (2003), Assessing the collection efficiency of Ross Sea sediment traps using ${ }^{230}$ Th and ${ }^{231} \mathrm{~Pa}$, Deep Sea Res., Part II, 50(3-4), 693-712.

François, R., M. A. Altabet, E. F. Yu, D. M. Sigman, M. P. Bacon, M. Frank, G. Bohrmann, G. Bareille, and L. D. Labeyrie (1997), Contribution of Southern Ocean surface water stratification to low atmospheric $\mathrm{CO}_{2}$ concentrations during the last glacial period, Nature, 389(6654), 929-935.

François, R., M. Frank, M. M. R. van der Loeff, and M. P. Bacon (2004), ${ }^{230}$ Th normalization: An essential tool for interpreting sedimentary fluxes during the late Quaternary, Paleoceanography, 19, PA1018, doi:10.1029/2003PA000939.

Gersonde, R., and U. Zielinski (2000), The reconstruction of late Quaternary Antarctic sea ice distribution: The use of diatoms as a proxy for sea ice, Palaeogeogr. Palaeoclimatol. Palaeoecol., 162(3-4), 263-286.

Gersonde, R., X. Crosta, A. Abelmann, and L. Armand (2005), Sea surface temperature and sea ice distribution of the Southern Ocean at the EPILOG Last Glacial Maximum: A circum-Antarctic view based on siliceous microfossil records, Quat. Sci. Rev., 24(7-9), 869-896.

Goericke, R. (2002), Top-down control of phytoplankton biomass and community structure in the monsoonal Arabian Sea, Limnol. Oceanogr. 47(5), 1307-1323.

Guihou, A., S. Pichat, A. Govin, S. Nave, E. Michel, J. C. Duplessy, P. Telouk, and L. Labeyrie (2011), Enhanced Atlantic meridional overturning circulation supports the Last Glacial Inception, Quat. Sci. Rev., 30(13-14), 1576-1582.

Hain, M. P., D. M. Sigman, and G. H. Haug (2010), Carbon dioxide effects of Antarctic stratification, North Atlantic Intermediate Water formation, and subantarctic nutrient drawdown during the last ice age: Diagnosis and synthesis in a geochemical box model, Global Biogeochem. Cycles, 24, GB4023, doi:10.1029/2010GB003790.

Hasle, G., and E. E. Syvertsen (1996), Marine diatoms, in Identifying Marine Diatoms and Dinoflagellates, edited by C. R. Tomas, pp. 5-385, Academic Press Limited, London.

Henderson, G. M., and R. F. Anderson (2003), The U-series toolbox for paleoceanography, Uranium-Ser. Geochem., 52, $493-531$.

Hillebrand, H., C. D. Dürselen, D. Kirschtel, U. Pollingher, and T. Zohary (1999), Biovolume calculation for pelagic and benthic microalgae, J. Phycol., 35(2), 403-424.

Hodell, D. A., K. A. Venz, C. D. Charles, and U. S. Ninnemann (2003), Pleistocene vertical carbon isotope and carbonate gradients in the South Atlantic sector of the Southern Ocean, Geochem. Geophys. Geosyst., 4(1), 1004, doi:10.1029/2002GC000367.

Horn, M. G., R. S. Robinson, T. A. Rynearson, and D. M. Sigman (2011), Nitrogen isotopic relationship between diatom-bound and bulk organic matter of cultured polar diatoms, Paleoceanography, 26, PA3208, doi:10.1029/2010PA002080.

Hurd, D. C. (1973), Interactions of biogenic opal, sediment and seawater in the central equatorial Pacific, Geochim. Cosmochim. Acta, 37, 2257-2282.

Jaccard, S. L., C. T. Hayes, A. Martínez-García, D. A. Hodell, R. F. Anderson, D. M. Sigman, and G. H. Haug (2013), Two modes of change in Southern Ocean productivity over the past million years, Science, 339(6126), 1419-1423.

Jacot Des Combes, H., O. Esper, C. L. De la Rocha, A. Abelmann, R. Gersonde, R. Yam, and A. Shemesh (2008), Diatom $\delta^{13} \mathrm{C}, \delta^{15} \mathrm{~N}$, and C/N since the Last Glacial Maximum in the Southern Ocean: Potential impact of species composition, Paleoceanography, 23, PA4209, doi:10.1029/ 2008PA001589.

Johnson, K. S., R. M. Gordon, and K. H. Coale (1997), What controls dissolved iron concentrations in the world ocean?, Mar. Chem., 57(3-4), 137-161.

Jouzel, J., et al. (2007), Orbital and millennial Antarctic climate variability over the past 800,000 years, Science, 317(5839), 793-796.

Keir, R. S. (1988), On the late Pleistocene ocean geochemistry and circulation, Paleoceanography, 3(4), 413-445, doi:10.1029/ PA003i004p00413.

Knapp, A. N., D. M. Sigman, and F. Lipschultz (2005), N isotopic composition of dissolved organic nitrogen and nitrate at the Bermuda Atlantic time series study site, Global Biogeochem. Cycles, 19, GB1018, doi:10.1029/2004GB002320.

Knox, F., and M. B. McElroy (1984), Changes in atmospheric $\mathrm{CO}_{2}$ : Influence of the marine biota at high-latitude, J. Geophys. Res., 89(D3), 4629-4637, doi:10.1029/JD089iD03p04629.

Kohfeld, K. E., C. Le Quéré, S. P. Harrison, and R. F. Anderson (2005), Role of marine biology in glacial-interglacial $\mathrm{CO}_{2} \mathrm{Cycles}$ Science, 308(5718), 74-78.

Kuhn, G. (2013), Don't forget the salty soup: Calculations for bulk marine geochemistry and radionuclide geochronology, Mineral. Mag., 77(5), 1519.

Kumar, N., R. Gwiazda, R. F. Anderson, and P. N. Froelich (1993), ${ }^{231} \mathrm{~Pa} /{ }^{230}$ Th ratios in sediments as a proxy for past changes in Southern Ocean productivity, Nature, 362(6415), 45-48. 
Lambert, F., B. Delmonte, J. R. Petit, M. Bigler, P. R. Kaufmann, M. A. Hutterli, T. F. Stocker, U. Ruth, J. P. Steffensen, and V. Maggi (2008), Dust-climate couplings over the past 800,000 years from the EPICA Dome C ice core, Nature, 452(7187), 616-619.

Lamy, F., R. Gersonde, G. Winckler, O. Esper, A. Jaeschke, G. Kuhn, J. Ullermann, A. Martínez-García, F. Lambert, and R. Kilian (2014), Increased dust deposition in the Pacific Southern Ocean during glacial periods, Science, 343(6169), 403-407.

Leventer, A. (1991), Sediment trap diatom assemblages from the Northern Antarctic Peninsula Region, Deep Sea Res., Part I, 38(8-9), 1127-1143.

Lourey, M. J., T. W. Trull, and D. M. Sigman (2003), Sensitivity of $\delta^{15} \mathrm{~N}$ nitrate, surface suspended and deep sinking particulate nitrogen to seasonal nitrate depletion in the Southern Ocean, Global Biogeochem. Cycles, 17(3), doi:10.1029/2002GB001973.

Lüthi, D., et al. (2008), High-resolution carbon dioxide concentration record 650,000-800,000 years before present, Nature, 453(7193), 379-382.

MacFarling Meure, C., D. Etheridge, C. Trudinger, P. Steele, R. Langenfelds, T. van Ommen, A. Smith, and J. Elkins (2006), Law Dome CO ${ }_{2}$, $\mathrm{CH}_{4}$ and $\mathrm{N}_{2} \mathrm{O}$ ice core records extended to 2000 years BP, Geophys. Res. Lett., 33, L14810, doi:10.1029/2006GL026152.

Marcott, S. A., et al. (2014), Centennial-scale changes in the global carbon cycle during the last deglaciation, Nature, 514, 616-619, doi:10.1038/nature13799.

Martin, J. H., R. M. Gordon, and S. E. Fitzwater (1990), Iron in Antarctic waters, Nature, 345(6271), 156-158.

Martínez-García, A., A. Rosell-Melé, W. Geibert, R. Gersonde, P. Masqué, V. Gaspari, and C. Barbante (2009), Links between iron supply, marine productivity, sea surface temperature, and $\mathrm{CO}_{2}$ over the last $1.1 \mathrm{Ma}$, Paleoceanography, 24, PA1207, doi:10.1029/2008PA001657.

Martínez-García, A., A. Rosell-Melé, S. L. Jaccard, W. Geibert, D. M. Sigman, and G. H. Haug (2011), Southern Ocean dust-climate coupling over the past four million years, Nature, 476(7360), 312-316.

Martínez-García, A., D. M. Sigman, H. J. Ren, R. F. Anderson, M. Straub, D. A. Hodell, S. L. Jaccard, T. I. Eglinton, and G. H. Haug (2014), Iron fertilization of the Subantarctic Ocean during the last ice age, Science, 343(6177), 1347-1350.

Meckler, A. N., H. J. Ren, D. M. Sigman, N. Gruber, B. Plessen, C. J. Schubert, and G. H. Haug (2011), Deglacial nitrogen isotope changes in the Gulf of Mexico: Evidence from bulk sedimentary and foraminifera-bound nitrogen in Orca Basin sediments, Paleoceanography, 26, PA4216, doi:10.1029/2011PA002156.

Mitchell, B. G., E. A. Brody, O. Holmhansen, C. McClain, and J. Bishop (1991), Light limitation of phytoplankton biomass and macronutrient utilization in the Southern Ocean, Limnol. Oceanogr., 36(8), 1662-1677.

Monnin, E., A. Indermühle, A. Dällenbach, J. Flückiger, B. Stauffer, T. F. Stocker, D. Raynaud, and J.-M. Barnola (2001), Atmospheric CO concentrations over the last glacial termination, Science, 291, 112-114.

Monnin, E., et al. (2004), Evidence for substantial accumulation rate variability in Antarctica during the Holocene, through synchronization of $\mathrm{CO}_{2}$ in the Taylor Dome, Dome C and DML ice cores, Earth Planet. Sci. Lett., 224, 45-54.

Morales, L. V., D. M. Sigman, M. G. Horn, and R. S. Robinson (2013), Cleaning methods for the isotopic determination of diatom-bound nitrogen in nonfossil diatom frustules, Limnol. Oceanogr. Methods, 11, 101-112, doi:10.4319/lom.2013.11.101.

Mortlock, R. A., C. D. Charles, P. N. Froelich, M. A. Zibello, J. Saltzman, J. D. Hays, and L. H. Burckle (1991), Evidence for lower productivity in the Antarctic Ocean during the last glaciation, Nature, 351(6323), 220-223.

Müller, P. J., and R. Schneider (1993), An automated leaching method for the determination of opal in sediments and particulate matter, Deep Sea Res., Part I, 40(3), 425-444

Nelson, D. M., P. Tréguer, M. A. Brzezinski, A. Leynaert, and B. Quéguiner (1995), Production and dissolution of biogenic silica in the ocean: Revised global estimates, comparison with regional data and relationship to biogenic sedimentation, Global Biogeochem. Cycles, 9(3), 359-372, doi:10.1029/95GB01070.

Petit, J. R., et al. (1999), Climate and atmospheric history of the past 420,000 years from the Vostok ice core, Antarctica, Nature, 399, 429-436.

Piotrowski, A. M., S. L. Goldstein, S. R. Hemming, and R. G. Fairbanks (2005), Temporal relationships of carbon cycling and ocean circulation at glacial boundaries, Science, 307(5717), 1933-1938.

Piotrowski, A. M., V. K. Banakar, A. E. Scrivner, H. Elderfield, A. Galy, and A. Dennis (2009), Indian Ocean circulation and productivity during the last glacial cycle, Earth Planet. Sci. Lett., 285(1-2), 179-189.

Rafter, P. A., P. J. DiFiore, and D. M. Sigman (2013), Coupled nitrate nitrogen and oxygen isotopes and organic matter remineralization in the Southern and Pacific Oceans, J. Geophys. Res. Oceans, 118, 4781-4794, doi:10.1002/jgrc.20316.

Reimer, P. J., et al. (2009), Intcal09 and Marine09 radiocarbon age calibration curves, 0-50,000 years cal BP, Radiocarbon, 51(4), 1111-1150.

Ren, H. J., D. M. Sigman, R. C. Thunell, and M. G. Prokopenko (2012), Nitrogen isotopic composition of planktonic foraminifera from the modern ocean and recent sediments, Limnol. Oceanogr., 57(4), 1011-1024.

Ren, H., D. M. Sigman, A. N. Meckler, B. Plessen, R. S. Robinson, Y. Rosenthal, and G. H. Haug (2009), Foraminiferal isotope evidence of reduced nitrogen fixation in the ice age Atlantic Ocean, Science, 323(5911), 244-248.

Robinson, R. S., and D. M. Sigman (2008), Nitrogen isotopic evidence for a poleward decrease in surface nitrate within the ice age Antarctic Quat. Sci. Rev., 27(9-10), 1076-1090.

Robinson, R. S., B. G. Brunelle, and D. M. Sigman (2004), Revisiting nutrient utilization in the glacial Antarctic: Evidence from a new method for diatom-bound N isotopic analysis, Paleoceanography, 19, PA3001, doi:10.1029/2003PA000996.

Robinson, R. S., D. M. Sigman, P. J. DiFiore, M. M. Rohde, T. A. Mashiotta, and D. W. Lea (2005), Diatom-bound ${ }^{15} \mathrm{~N} /{ }^{14} \mathrm{~N}$ : New support for enhanced nutrient consumption in the ice age subantarctic, Paleoceanography, 20, PA3003, doi:10.1029/2004PA001114.

Robinson, R. S., et al. (2012), A review of nitrogen isotopic alteration in marine sediments, Paleoceanography, PA4203, 27, doi:10.1029/ 2012PA002321.

Rubino, M., et al. (2013), A revised 1000 year atmoshperic $\delta{ }^{13} \mathrm{C}-\mathrm{CO}_{2}$ record from Law Dome and South Pole, Antarctica, J. Geophys. Res. Atmos., 118, 8482-8499, doi:10.1002/jgrd.50668.

Sarmiento, J. L., and J. R. Toggweiler (1984), A new model for the role of the oceans in determining atmospheric $p \mathrm{CO}_{2}, \mathrm{Nature}, 308(5960)$ 621-624.

Sarmiento, J. L., N. Gruber, M. A. Brzezinski, and J. P. Dunne (2004), High-latitude controls of thermocline nutrients and low latitude biological productivity, Nature, 427(6969), 56-60.

Savidge, G., P. Boyd, A. Pomroy, D. Harbour, and I. Joint (1995), Phytoplankton production and biomass estimates in the northeast Atlantic Ocean, May-June 1990, Deep Sea Res., Part I, 42(5), 599-617.

Schlitzer, R. (2002), Interactive analysis and visualization of geoscience data with Ocean Data View, Comput. Geosci., $28(10), 1211-1218$.

Schneider, R., J. Schmitt, P. Köhler, F. Joos, and H. Fischer (2013), A reconstruction of atmospheric carbon dioxide and its stable carbon isotopic composition from the penultimate glacial maximum to the last glacial inception, Clim. Past, 9, 2507-2523, doi:10.5194/cp-9-2507-2013.

Schrader, H. J., and R. Gersonde (1987), Diatoms and silicoflagellates, in Micropaleontological Methods and Techniques: An Exercise on an Eight Meter Section of the Lower Pliocene of Capo Rossello, Sicily, edited by W. J. Zachariasse et al., pp. 129-176, Micropaleontol. Bull., Utrecht. 
Schubert, C. J., and S. E. Calvert (2001), Nitrogen and carbon isotopic composition of marine and terrestrial organic matter in Arctic Ocean sediments: Implications for nutrient utilization and organic matter composition, Deep Sea Res., Part I, 48(3), 789-810.

Shemesh, A., L. H. Burckle, and P. N. Froelich (1989), Dissolution and preservation of Antarctic diatoms and the effect on sediment thanatocoenoses, Quat. Res., 31, 288-308.

Siegenthaler, U., and T. Wenk (1984), Rapid atmospheric $\mathrm{CO}_{2}$ variations and ocean circulation, Nature, 308(5960), $624-626$.

Sigman, D. M., K. L. Casciotti, M. Andreani, C. Barford, M. Galanter, and J. K. Böhlke (2001), A bacterial method for the nitrogen isotopic analysis of nitrate in seawater and freshwater, Anal. Chem., 73(17), 4145-4153.

Sigman, D. M., S. L. Jaccard, and G. H. Haug (2004), Polar ocean stratification in a cold climate, Nature, 428(6978), 59-63.

Skinner, L. C., S. Fallon, C. Waelbroeck, E. Michel, and S. Barker (2010), Ventilation of the deep Southern Ocean and deglacial $\mathrm{CO}_{2}$ rise, Science, 328(5982), 1147-1151.

Straub, M., D. M. Sigman, H. J. Ren, A. Martínez-García, A. N. Meckler, M. P. Hain, and G. H. Haug (2013a), Changes in North Atlantic nitrogen fixation controlled by ocean circulation, Nature, 501(7466), 200-203.

Straub, M., M. M. Tremblay, D. M. Sigman, A. S. Studer, H. Ren, J. R. Toggweiler, and G. H. Haug (2013b), Nutrient conditions in the subpolar North Atlantic during the last glacial period reconstructed from foraminifera-bound nitrogen isotopes, Paleoceanography, 28, 79-90, doi:10.1002/palo.20013.

Studer, A. S., A. Martínez-García, S. L. Jaccard, F. E. Girault, D. M. Sigman, and G. H. Haug (2012), Enhanced stratification and seasonality in the Subarctic Pacific upon Northern Hemisphere Glaciation-New evidence from diatom-bound nitrogen isotopes, alkenones and archaeal tetraethers, Earth Planet. Sci. Lett., 351, 84-94.

Studer, A. S., K. K. Ellis, S. Oleynik, D. M. Sigman, and G. H. Haug (2013), Size-specific opal-bound nitrogen isotope measurements in North Pacific sediments, Geochim. Cosmochim. Acta, 120, 179-194.

Stuiver, M., and P. J. Reimer (1986), A computer program for radiocarbon age calibration, Radiocarbon, 28(2B), $1022-1030$.

Sunda, W. G., and S. A. Huntsman (1997), Interrelated influence of iron, light and cell size on marine phytoplankton growth, Nature, 390(6658), 389-392.

Toggweiler, J. R. (1999), Variation of atmospheric $\mathrm{CO}_{2}$ by ventilation of the ocean's deepest water, Paleoceanography, 14(5), 571-588, doi:10.1029/1999PA900033.

Toggweiler, J. R., J. L. Russell, and S. R. Carson (2006), Midlatitude westerlies, atmospheric $\mathrm{CO}_{2}$, and climate change during the ice ages, Paleoceanography, 21, PA2005, doi:10.1029/2005PA001154.

Tréguer, P., and G. Jacques (1992), Dynamics of nutrients and phytoplankton, and fluxes of carbon, nitrogen and silicon in the Antarctic Ocean, Polar Biol., 12, 149-162.

Wacker, L., J. Lippold, M. Molnar, and H. Schulz (2013), Towards radiocarbon dating of single foraminifera with a gas ion source, Nucl. Instrum Methods Phys. Res., Sect. B, 294, 307-310.

Waser, N. A. D., P. J. Harrison, B. Nielsen, S. E. Calvert, and D. H. Turpin (1998), Nitrogen isotope fractionation during the uptake and assimilation of nitrate, nitrite, ammonium, and urea by a marine diatom, Limnol. Oceanogr., 43(2), 215-224.

Zielinski, U., and R. Gersonde (1997), Diatom distribution in Southern Ocean surface sediments (Atlantic sector): Implications for paleoenvironmental reconstructions, Palaeogeogr. Palaeoclimatol. Palaeoecol., 129(3-4), 213-250.

Zielinski, U., and R. Gersonde (2002), Plio-Pleistocene diatom biostratigraphy from ODP Leg 177, Atlantic sector of the Southern Ocean, Mar. Micropaleontol., 45, 225-268. 